\title{
MEMORIAL TREES IN THE CZECH LANDSCAPE
}

\author{
JAROMÍRA DRESLEROVÁ
}

Department of Forest Botany, Dendrology and Biogeocoenology, Mendel University in Brno, email: j.dreslerova@seznam.cz.

Received: $16^{\text {th }}$ August 2017, Accepted: $6^{\text {th }}$ September 2017

\begin{abstract}
The aim of the article is to assess the extensive database of memorial trees operated by AOPK CR (Nature Conservation Agency of the Czech Republic) and to determine the occurrence and abundance of the most monumental trees in chosen biogeographical units, (altitudinal vegetation zone, altitude, ecological series (Buček \& Lacina, 2002), province, subprovince, bioregion (Culek et. al., 1996)) and the maximum size and age they can reach in these units.

This assessment of monumental trees at a national level was made possible based on the provision of two extensive databases containing the information about the trees (AOPK CR Database of Memorial Trees) and about the biogeographical units of the Czech Republic (Biogeographical Registry of the Czech Republic). Basic unit of both databases is cadastral area and the fact allowed to link the data and to evaluate them. The occurrence rate of memorial trees and species in individual cadastral areas and in biogeographical regions is presented in the map outputs.
\end{abstract}

Keywords: memorial trees, monumental trees, biogeographical units of the Czech Republic, species range, growth parameters

\section{INTRODUCTION}

Memorial trees are extremely important trees, their groups and alleys, which can be decreed by the resolution of nature conservation body after the fulfilment of all requirements prescribed by law. Memorial trees excel by their growth and age. They represent prominent landscape dominants, especially so the significant introduced tree species and, finally yet importantly, the historically valuable trees, which remind of memorable events or relate to various legends and fables (Reš, 1998). Alexander von Humboldt, Professor of Berlin University, was first to denote massive trees as nature monuments when he saw them at his scientific expedition to South America in 1799 - 1804 (Kyzlík et. al., 2003).

A majority of the memorial trees are solitaires. Solitary old trees occur in our country usually at important places, especially on road crossings, near entrances to fields or as landmarks in the landscape. People used to plant them to delimitate boundaries of individual land properties, cadastres or estates, where the trees provided shelter and shade not only to them but also to cattle (Štěpánek, 2004; Hageneder, 2003).

Dispersed vegetation creates favourable site conditions for the occurrence of fungi, invertebrates living in the cavities of decaying trees or for epiphytic mosses and lichens (Rose, 1992; Read, 1996; 2000; Alexander, 1998; Buttler et al., 2001). Forest animals and 
birds actively search solitary woody plants for food, as a hiding place or to nest and breed. For predatory birds, solitary trees in the landscape are necessary (Zejda, 1980; Smith et al., 1992; Harding \& Wall, 2000). The existence of dispersed vegetation also indirectly helps in the biological control of pests (Zejda, 1980).

The first reference to the protection of trees dates back to the Middle Ages and was closely related to forest care. One of the oldest preserved directives on forest management and penalties for damages to forest is "The Law of the Bohemian Prince Konrad Ota" from approx. 1189. Sanctions for illegal felling of trees can be found also in the Jihlava Town Law and in the book of the old lord of Rosenberg from approx. 1360. A reference to the prohibition of damaging and needless felling of trees is also in the draft of Majestas Carolinas by Charles IV from 1348, in Chapter 50. On the pressure of baronial council, Charles IV cancelled the Majestas Carolinas in 1355. In 1754, Maria Theresa issued a "Forest Order", which was at its time a progressive and meticulous regulation for the protection and management of forests (Michálek, 2005).

The history of memorial trees protection at the turn of the $19^{\text {th }}$ and $20^{\text {th }}$ centuries is closely connected with the emergence and work of beautifying societies in our country. On 30 October 1904, a union of Czech beautifying societies in the Kingdom of Bohemia was established in Prague ("U Choděrü"). From 1905, its name was the Union of Czech Beautifying Societies in Bohemia, Moravia and in Silesia. After the establishment of the Czechoslovak Republic, the Union changed its name to the Union of Czechoslovak Societies for Homeland Beautifying and Protection in Prague. From 1904 to the early 1950s, the Union issued an interesting periodical "The Beauty of Our Home", which reappeared thanks to the Czech Union for Nature Conservation (CSOP), and in which we can find data on the protection of memorial trees even today (Michálek, 2005).

In 1899, Jan Evangelista Chadt Ševětínský published the first list of memorial trees in Bohemia. The same author published a registry on "Old and monumental trees in Bohemia, Moravia and in Silesia" in the journal "Český lid" (Czech People), Vol. XVII in 1908 and in a special offprint, with the description of 165 rare trees and 30 pictures. A supplemented edition with the characterizations of 320 rare trees and 160 images of monumental individuals was issued in Písek in 1913, and later as a separate chapter in the book named "History of Forests and Forestry". This list is the first comprehensive inventory of memorial trees in the Czech lands (Chadt, 1913).

Memorial trees are currently legally proclaimed pursuant to Act no. 114/1992 Sb. by the resolution of competent nature conservation body (e.g. Administration of National Park, Protected Landscape Area, empowered municipal authorities etc.). The memorial trees are included in the publicly accessible central list of nature conservation administered by AOPK ČR (Reš, 1998). The current directory of decreed "Memorial Trees" was gradually issued as part of the edition "Protected Areas of the Czech Republic" (Mackovčin \& Sedláček, 1999-2009). The ensemble of memorial trees is not closed to extremely valuable introduced tree species either (Reš \& Štěrba, 2010).

Another source dealing with the current monumental and memorial trees is the work compiled by the collective of authors Tábor et. al. (1998, 2001, 2002, 2003, 2004, 2005) who focused namely on evaluating the occurrence of memorial trees registered in the AOPK CR database in individual regions (administrative regions and districts) and on selecting suitable specimens determined for the conservation of genetic resources of these memorial trees.

Massive and memorial trees at a regional level are mentioned in a number of tourist guides relating to regional history and geography (Modrý, 2004; Kubačka \& Kubáčková, 2005; Hrubá \& Valentová, 2005; Hrušková, 2008; a.o.) or in publications evaluating the memorial 
trees as objects of folklore character, trees with legends and fables etc. (Hrušková \& Turek et. al., 1986; 1995; 1999; 2001; 2005; Hrušková \& Turek, 2003).

Most countries in Europe have the protection of monumental trees enacted directly by legislation or by local decrees. Characteristics or criteria classifying the trees as significant are identical in a majority of countries and are in line with the above presented definition of memorial trees. Thus, memorial trees are considered natural cultural heritage, which has to be protected and preserved (ZTV-Baumpflege, 1992; Domínguez, 2010; Circulaire ministérielle, 2008; Ustawa o ochronie przyrody, 2004; Zákon o ochraně přírody a krajiny, 2003; Tutela e valorizzazione degli alberi monumentali, 2005; a.o.). For example, one of the first laws on nature conservation in Sweden from 1909 included the protection of trees. In Austria, a similar law has existed since 1913, in Italy since 1939 and in Poland since 1934 (Symonides, 2007; Mittmannsgruber, 2011; Anonymus, 1998).

\section{MATERIAL AND METHODS}

The assessment of monumental trees at a national level was made possible by using two extensive databases containing information on memorial trees (AOPK CR Database of memorial trees) and on biogeographical units of the Czech Republic (Biogeographical Registry of the Czech Republic). Basic unit of the two databases is cadastral area and this made it possible to link the available data and evaluate them.

The occurrence rate of memorial trees and species in individual cadastral areas and in biogeographical regions is presented in map outputs. The maps were plotted in the ArcMap programme. The base map of bioregions was taken over from the Biogeographical Division of the Czech Republic (Culek et. al., 1996).

\section{Evaluation of the Database of Memorial Trees of the Czech Republic}

The Central List AOPK CR includes the characterization, positioning, legal and technical documentation of memorial trees, their buffer zones, and a list of contractually protected memorial trees proclaimed pursuant to $\S 39$ of Act no. 114/1992 Sb. on nature conservation and landscape protection, occurring in the territory of the Czech Republic.

On 31 December 2006, AOPK CR provided a shortened extract with fundamental data on the memorial trees - a so-called AOPK CR database of memorial trees - containing basic dendrological characteristics, GPS coordinates, health condition and reason for protection, and other information to each memorial tree. For the purpose of this study, we used the data on girth, height, crown size (width and height, namely in pedunculate oak Quercus robur) and age of memorial trees.

\section{Biogeographical registry}

Data from the AOPK CR database of memorial trees were linked with the data from the Biogeographical Registry. The assessment of memorial trees was focused primarily on growth dimensions, and on the abundance of these trees in the individual altitudinal vegetation zones and other units of the biogeographical division of the landscape (bioregions).

The Biogeographical Registry contains landscape typification in cadastral areas and provides for creating an overall conception about the natural condition of biogeocoenoses in the landscape, which is a good basis for the comparison of changes occurring due to human activities (Zlatník, 1973). The Registry includes data about the distribution of superstructural units of biogeocoenological landscape typification (altitudinal vegetation zones, hydric and trophic series) in ca. 12,900 cadastral areas of the Czech Republic. 
Basic element of the Biogeographical Registry is cadastral area. Affiliation to the superstructural units of biogeocoenological typification (Buček \& Lacina, 2002) was coded for each cadastral area, which is characterized by three data in the following order:

\section{Code of altitudinal zonality - Code of trophic series - Code of hydric series}

Since a greater part of the cadastral areas are heterogeneous in terms of superstructural units, the coding had to be adapted and include characteristic combinations of linked altitudinal vegetation zones (Tab. 1) (Buček \& Lacina, 1988).

Table 1: Coding units of altitudinal vegetation zonality (Buček \& Lacina, 1988)

\begin{tabular}{|c|c|}
\hline AVZ - 1 & 1 - Oak $100 \%$ \\
\hline AVZ - 2 & 2- Oak 70-90\% (Beech-oak 1-30\%) \\
\hline AVZ - 3 & 3- Oak 50-70\% (Beech-oak 30-50\%) \\
\hline$A V Z-4$ & 4 - Beech-oak $100 \%$ \\
\hline AVZ - 5 & 5 - Beech-oak 50-70\% (Oak 30-50\%) \\
\hline AVZ - 6 & 6 - Beech-oak 50-70\% (Oak-beech 30-50\%) \\
\hline AVZ - 7 & 7 - Oak-beech $100 \%$ \\
\hline AVZ - 8 & 8 - Oak-beech $50-70 \%$ (Beech-oak 30-50\%) \\
\hline AVZ - 9 & 9 - Oak-beech 50-70\% (Beech 30-50\%) \\
\hline AVZ - 10 & 10 - Beech $100 \%$ \\
\hline AVZ - 11 & 11 - Beech $50-70 \%$ (Oak-beech $30-50 \%$ ) \\
\hline AVZ - 12 & 12 - Beech $50-70 \%$ (Fir-beech $30-50 \%$ ) \\
\hline AVZ - 13 & 13 - Oak coniferous $100 \%$ \\
\hline AVZ - 14 & 14 - Oak coniferous $50-70 \%$ (Oak-beech $30-50 \%$ ) \\
\hline AVZ - 15 & 15 - Beech $30-50 \%$ (Oak coniferous $30-70 \%$ ) \\
\hline AVZ - 16 & 16 - Oak coniferous $50-70 \%$ (Fir-beech $30-50 \%$ ) \\
\hline AVZ - 17 & 17 - Fir-beech $100 \%$ \\
\hline AVZ - 18 & 18 - Fir-beech $50-70 \%$ (Beech $30-50 \%$ ) \\
\hline AVZ - 19 & 19 - Fir-beech $50-70 \%$ (Beech 30-50\%, Spruce-fir-beech 1-30\%) \\
\hline AVZ - 20 & 20 - Fir-beech $70-90 \%$ (Spruce-fir-beech 1-30\%) \\
\hline AVZ - 21 & 21 - Fir-beech $50-70 \%$ (Spruce-fir-beech $30-50 \%$ ) \\
\hline AVZ - 22 & 22 - Spruce-fir-beech $50-70 \%$ (Fir-beech $30-50 \%$ ) \\
\hline AVZ - 23 & 23 - Fir-beech $50-70 \%$ (Spruce-fir-beech $30-50 \%$, Spruce $1-20 \%$ ) \\
\hline AVZ - 24 & 24 - Spruce-fir-beech $50-70 \%$ (Spruce $30-50 \%$ ) \\
\hline AVZ - 25 & 25 - Spruce-fir-beech $50-70 \%$ (Spruce $30-50 \%, 1-20 \%$ Dwarf-pine and Alpine) \\
\hline AVZ - 26 & 26 - Spruce-fir-beech $100 \%$ \\
\hline
\end{tabular}

Altitudinal vegetation zonality of cadastral areas of the Czech Republic is characterized by 26 coding symbols, of which 7 are homogeneous and 19 are heterogeneous. The content of heterogeneous codes for Altitudinal Vegetation Zones (AVZ) 1 - 9 was defined so that it features the predominant altitudinal zone $(50-70 \%$ of cadastre area) and the linking altitudinal zone (30 - $50 \%$ of cadastre area) (Buček \& Lacina, 1988).

Higher level of biogeographical division of the Czech Republic is represented by biogeographical regions (Culek et. al., 1996). Bioregions are in terms of biota original parts of landscape and have to meet the following criteria: The given territory has a specific combination of the groups of biogeocoene types and types of biochores. It features typical geoelements, migrants and relicts. In the flat relief, the delimitated territory has to belong to the same sea drainage area. The entire territory has to be spatially compact and its area has to 
be larger than $100 \mathrm{~km}^{2}$ (Culek et. al., 1996). The Czech territory is crossed by the boundaries of two biogeographical provinces - Pannonian and that of Central European deciduous forests (Meusel, 1965), which are further divided into four subprovinces (Buček et al.. 1992). In the territory of the Czech Republic, 90 bioregions are distinguished (Culek et. al., 1996). The assessment of memorial trees consisted in the evaluation of growth parameters and occurrence rate of individual species in the bioregions, provinces and subprovinces.

\section{RESULTS}

\section{Evaluation of the species spectrum and growth of memorial trees}

The extensive AOPK CR database of memorial trees included 26,262 trees to the date of 31 December 2006. Representation of individuals recorded in the cadastral areas is presented in Map Attachment No. 1. (see Apendix).

There are 5,479 items, into which the trees are divided according to their formation in the terrain. To the mentioned date, the database included 14,889 trees in linear formations (239 items), 3,474 trees (3,462 items) registered as solitaires and 7,704 trees (1,770 items) occurring in the tree groups. The smallest number of memorial trees (191 trees in 4 items) falls into the "stand" category. All data on numbers should be considered indicative since the total number of trees is continuously changing.

\section{Species spectrum of memorial trees}

The database of memorial trees includes 124 taxa (species, cultivars and hybrids). Autochthonous are 50 species and 14 cultivars. The remaining 60 species are allochthonous in the Czech Republic. The most abundant species are as follows: small-leaved linden (Tilia cordata) with 8,798 trees (1,737 items) and pedunculate oak (Quercus robur) with 4,050 trees recorded in 1,271 items. More than a thousand of trees decreed as memorial trees have horse chestnut (Aesculus hippocastanum) with 2,277 individuals in 95 items, large-leaved linden (Tilia platyphyllos) with 1,850 individuals in 590 items, European ash (Fraxinus excelsior) with 1,295 individuals in 155 items and sycamore maple (Acer pseudoplatanus) with 1,005 individuals in 173 items (Map Attachment No. 2 - see Apendix).

\section{Growth parameters of recorded tree species}

The range of girths gauged at breast height is $100 \mathrm{~cm}-1,252 \mathrm{~cm}$. According to the database, the most monumental trees in the Czech Republic are two large-leaved lindens (Tilia platyphyllos) - one is the Vejdova linden at Pastviny (girth 1,225 cm) and the second one is the Sudslavická linden (girth $1,150 \mathrm{~cm}$ ). Other giant trees include the Tatrovická linden - small-leaved linden (Tilia cordata) (girth 1,122 cm) near Tatrovice in the Sokolov district, and the Žižka's oak - pedunculate oak (Quercus robur) (girth 1,003 cm) in Náměšt' nad Oslavou. A leading representative of conifers in the database of memorial trees of the Czech Republic is the giant sequoia (Sequoiadendron giganteum) in Chabaně (girth $612 \mathrm{~cm}$ ), which is followed by a European larch (Larix decidua) near Petrovice (girth $550 \mathrm{~cm}$ ) and a Norway spruce (Picea abies) in the Slavická game preserve (girth $520 \mathrm{~cm}$ ).

Interesting are dimensions of the field maple (Acer campestre) in Čížkov (girth $470 \mathrm{~cm}$ ), the Adamcova service tree (Sorbus domestica) (girth $460 \mathrm{~cm}$ ) or the Pastýřova pear (Pyrus communis) (girth $435 \mathrm{~cm}$ ). Monumental conifers include the Vopařilova fir (Abies alba) (girth $450 \mathrm{~cm}$ ) or common yews (Taxus baccata) at Krompach (girth $460 \mathrm{~cm}$ ) (Map Attachment No. 3 - see Apendix).

The highest representation among the memorial trees have individuals with girths ranging from $300-350 \mathrm{~cm}(16.1 \%$ ) (Fig. 1). As to the diversity of species composition, the most 
abundant is the girth category of $250-300 \mathrm{~cm}$ with 58 species. Similarly as in a majority of girth categories, most abundant in this category are the specimens of small-leaved linden (Tilia cordata). Exceptional is the girth category of $201-250 \mathrm{~cm}$, which is dominated by individuals of horse chestnut (Aesculus hippocastanum). Most abundant in larger girth categories $(651-850 \mathrm{~cm}$ ) are individuals of pedunculate oak (Quercus robur) and the largest girth category $(851 \mathrm{~cm}$ and more) includes predominantly the specimens of large-leaved linden (Tilia platyphyllos).

Fig. 1: Representation of memorial trees and species in girth categories
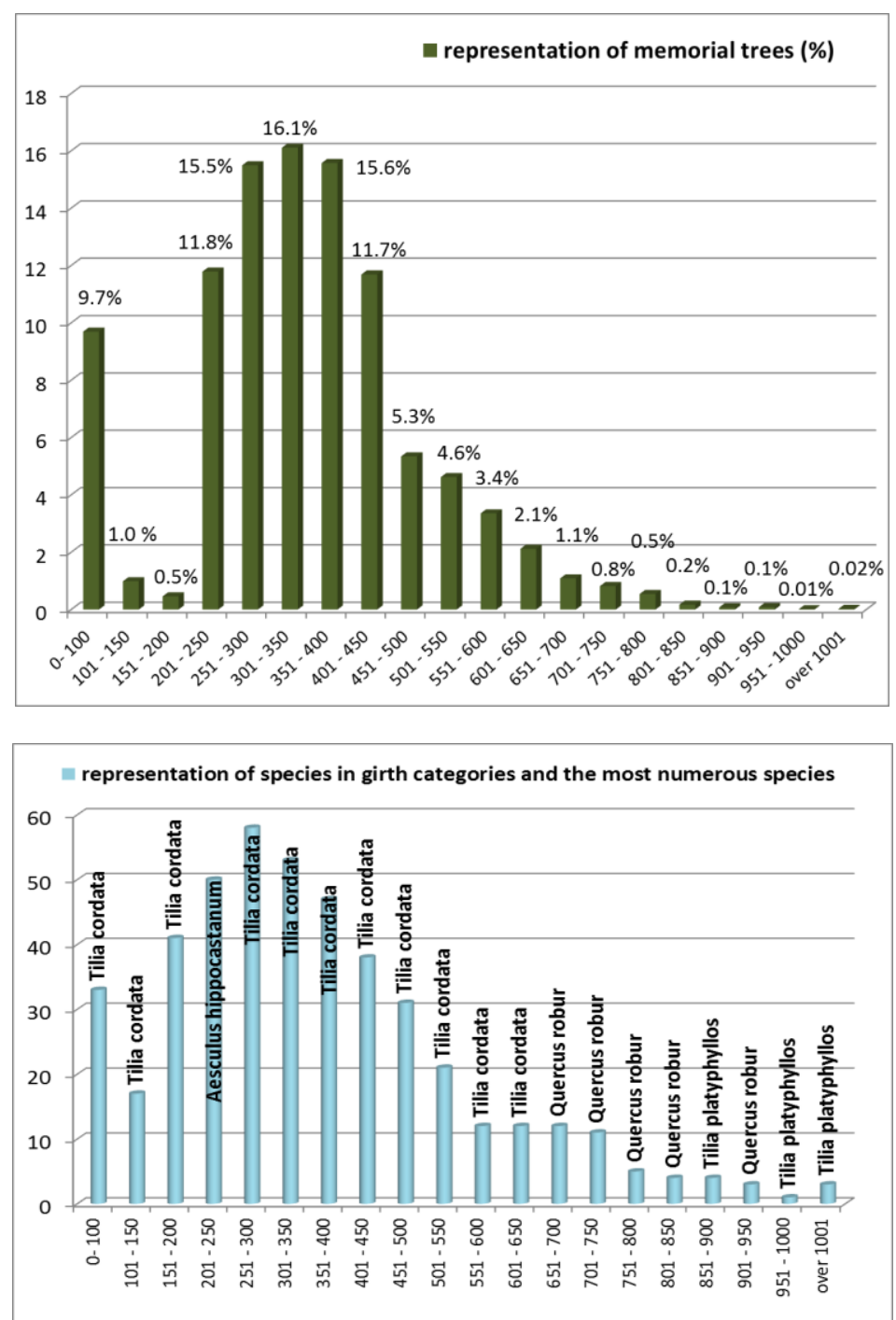

Maximum tree heights of individual species range from about $2 \mathrm{~m}$ up to giants tall over $55 \mathrm{~m}$. The tallest trees in the database are conifers. The largest specimen is a European larch (Larix decidua) called Larch the Trey in Habrůvka with a total height of $58 \mathrm{~m}$ and girth 
$448 \mathrm{~cm}$, which is followed by the Fremuth's silver fir (Abies alba) near the village of Čerchov, with a height of $55 \mathrm{~m}$ and girth $386 \mathrm{~cm}$. The first broadleaved representatives, which succeeded in making their way among the tallest trees, are London planes (Platanus $x$ acerifolia). The tallest individual is the Plane at St. Anne with a height of $47 \mathrm{~m}$ and girth $571 \mathrm{~cm}$; the second one is a plane in Běstvina with a height of $46 \mathrm{~m}$ and girth $565 \mathrm{~cm}$. The database also contains specimens of black poplar (Populus nigra) and large-leaved linden (Tilia platyphyllos) with a height of $45 \mathrm{~m}$.

\section{Occurrence of memorial trees in units of biogeographical division}

\section{Occurrence of memorial trees in altitudinal vegetation zones}

Most decreed memorial trees fall in the Beech altitudinal vegetation zone (AVZ 10, $18.2 \%)$. High numbers of memorial trees occur also in the Oak-Beech (AVZ 7, 17.2\%) and the Fir-Beech (AVZ 17, $12.5 \%$ ) altitudinal vegetation zones (Fig. 2).

The species most abundant in the concerned units of altitudinal vegetation zonality is small-leaved linden (Tilia cordata), occurring from the Oak (AVZ 7) to the Fir-Beech (AVZ 12) altitudinal vegetation zones, and pedunculate oak (Quercus robur) occurring most in five AVZ units, of which its greatest representation is in the Beech-Oak (AVZ 4) and in the Beech (AVZ 10) altitudinal vegetation zones including the Oak-Coniferous variant (AVZ 13) (Fig. 3).

Interesting is that the most abundant tree species in the Oak altitudinal vegetation zone is London plane (Platanus $x$ acerifolia, AVZ 1) and service tree (Sorbus domestica, AVZ 2), which are complemented by large-leaved linden (Tilia platyphyllos, AVZ 3) (Fig. 3).

The below table presents the maximum growth values and age reached by memorial trees in the respective coding units of the given altitudinal vegetation zone (Tab. 4). Individuals with the largest girth occur in the Fir-Beech altitudinal vegetation zone (Tilia platyphyllos with 1,252 and 1,150 cm, AVZ 17 and AVZ 18), in the Beech altitudinal vegetation zone (Tilia cordata with $1,122 \mathrm{~cm}, \mathrm{AVZ} 12$ ) and in the Oak-Beech altitudinal vegetation zone (Quercus robur with 1,003 cm, AVZ 7). The oldest specimens occur on the dividing line between the Beech-Oak and Oak-Beech altitudinal vegetation zones (AVZ 6, 7) and between the Oak-Beech and Beech altitudinal vegetation zones (AVZ 9, 10). The oldest tree at the highest altitude (Tilia platyphyllos) occurs in the Fir-Beech altitudinal vegetation zone (AVZ 17). The data on age should be considered of informative value only as they are often estimated or taken over from local historical sources. 
Dreslerová J.: Memorial trees in the Czech landscape

\section{Fig. 2: Representation of memorial trees in altitudinal vegetation zones in percent}

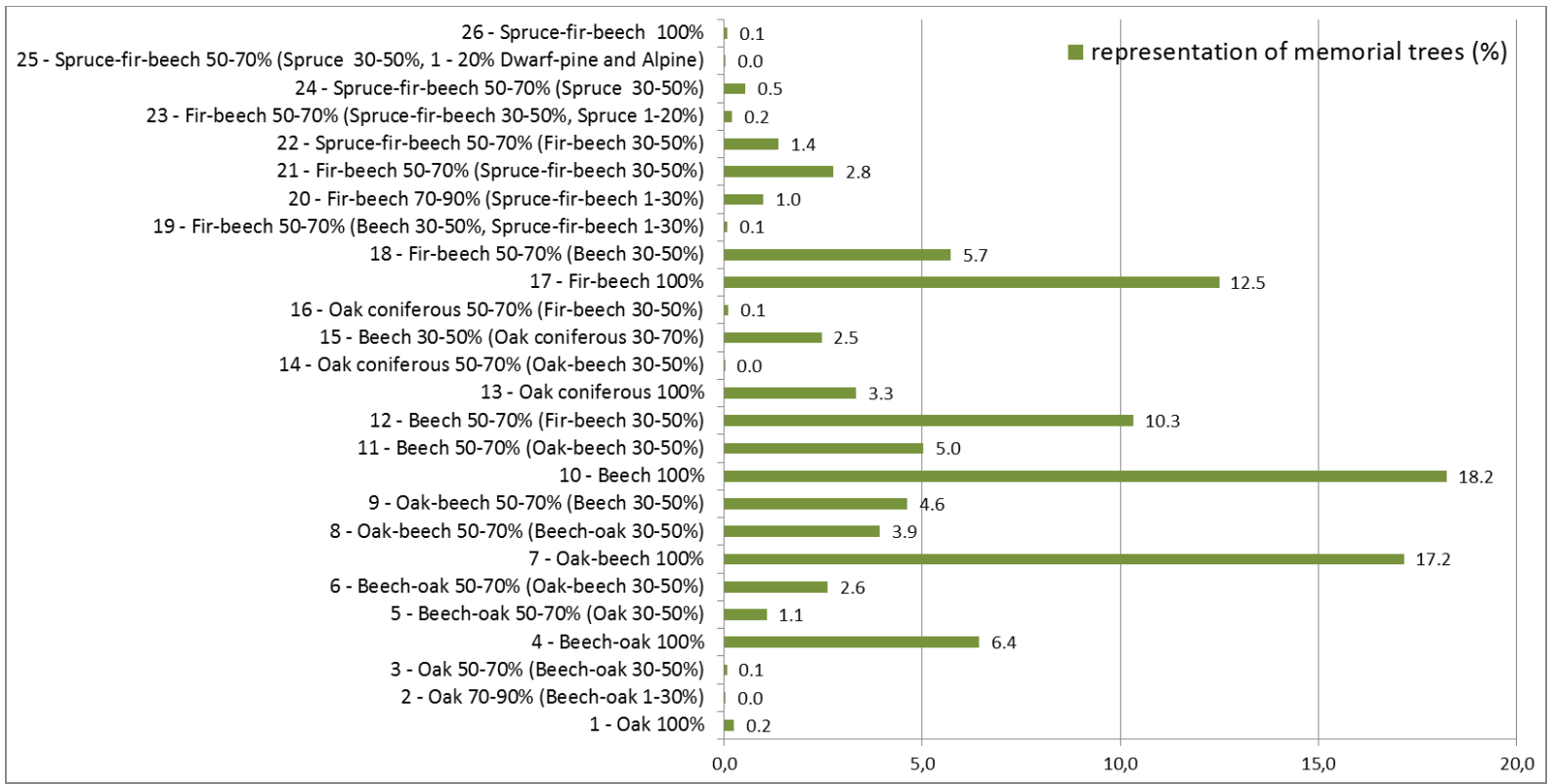

Fig. 3: Species diversity in altitudinal vegetation zones and representation of the most abundant species (\%)

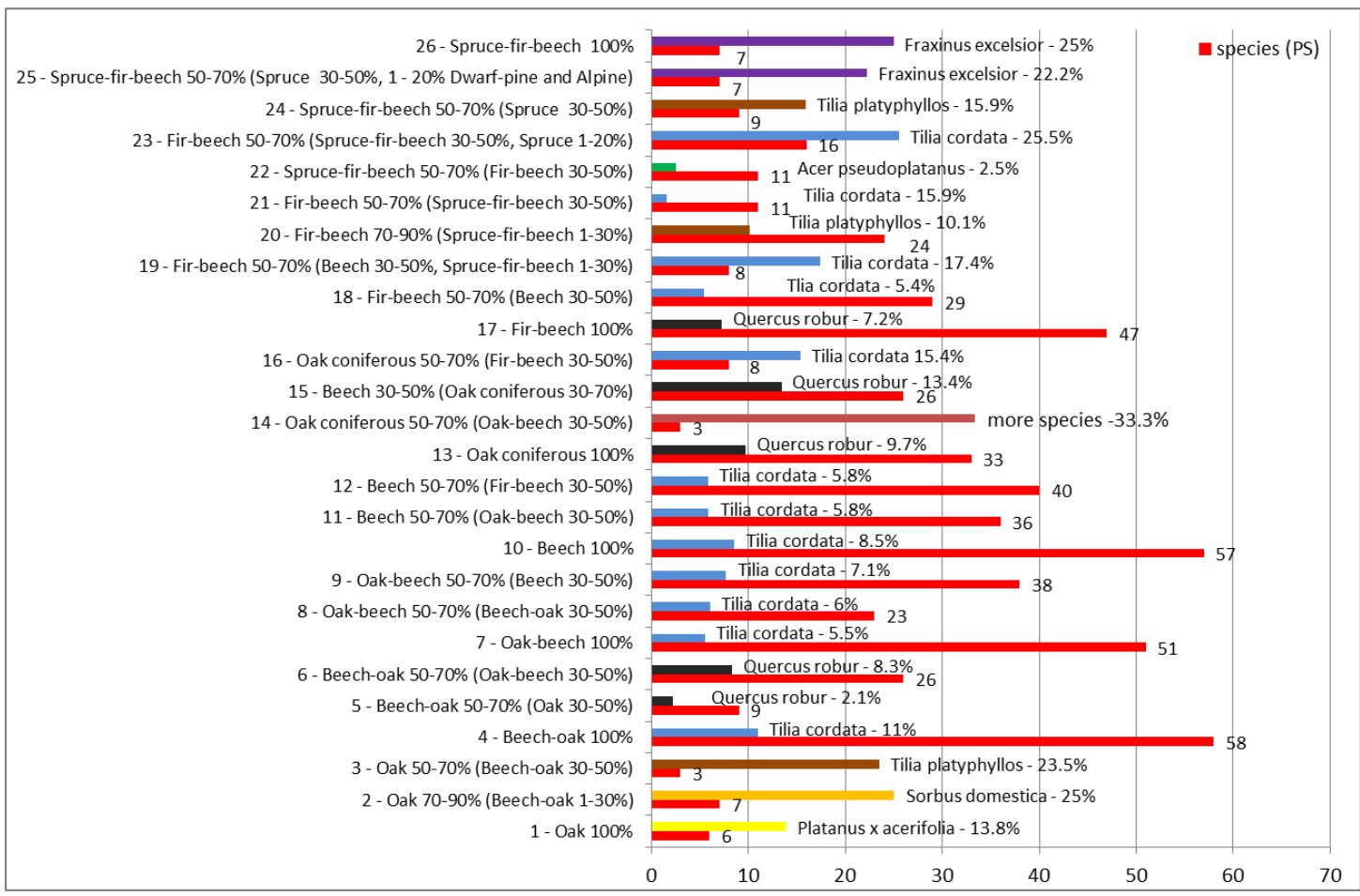


Table 4: Growth characteristics of trees in altitudinal vegetation zones

\begin{tabular}{|c|c|c|c|c|c|c|c|c|c|c|c|c|c|c|c|c|c|c|c|c|c|c|c|c|}
\hline & 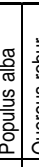 & 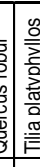 & & & & & & & & & & & & & & 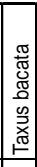 & & & & & & & \\
\hline & & ৪্ল & ক্ষ & & & c & б & 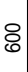 & 응 & 응 & 8 & & & & & 음 & প & & 8 & g্ & & & & \\
\hline.$\frac{a v}{0}$ & 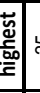 & & & f & 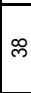 & $\bar{\gamma}$ & \& & 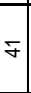 & $|q|$ & 9 & $\stackrel{\infty}{\infty}$ & F & me & & $\approx$ & 8 & F & $\mathcal{F}$ & 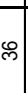 & & $\stackrel{f}{q}$ & & & \\
\hline$\overline{5}$ & & & 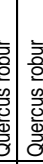 & 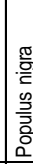 & 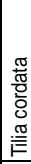 & 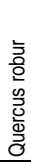 & $\begin{array}{l}\overline{0} \\
0 \\
0 \\
0 \\
0 \\
0 \\
0 \\
0 \\
0\end{array}$ & 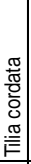 & 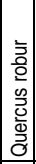 & 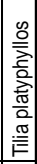 & 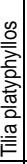 & 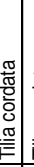 & 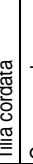 & 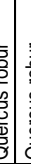 & & 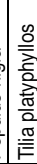 & 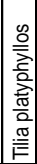 & 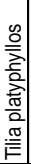 & 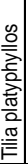 & 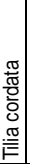 & 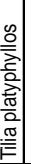 & & & \\
\hline & ثّ. & & 怘 & $\infty$ & ఊ & চ & 各 & ১০ & ৪ి & 过 & ֶֶ, & & 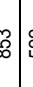 & & \& & & 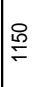 & $\frac{m}{i}$ & & 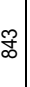 & ฉ్ & & & \\
\hline & 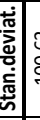 & & & & 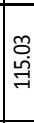 & $\begin{array}{l}\text { 点 } \\
\stackrel{9}{G}\end{array}$ & $\begin{array}{l}\infty \\
\stackrel{2}{2}\end{array}$ & 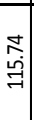 & 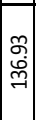 & $\mid$\begin{tabular}{l}
$n$ \\
\multirow{2}{*}{} \\
$\dot{y}$
\end{tabular} & må & 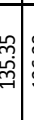 & 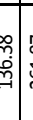 & & & & $\begin{array}{l}0 \\
\text { : } \\
\text { శ్ }\end{array}$ & $\begin{array}{l}\mathscr{8} \\
\text { Sं }\end{array}$ & $\stackrel{\sim}{\rightarrow}$ & 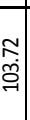 & & & & \\
\hline & & & & 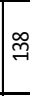 & శ్తి & $\stackrel{\sim}{\circ}$ & $\exists$ & $\vec{\sigma}$ & $\exists$ & 혹 & กิ & & & & $\overline{\tilde{S}}$ & & & $\tilde{\Xi}$ & & 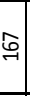 & 고 고 & & & \\
\hline & 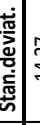 & $\underset{\sim}{-1}$ & & & & ת. & $\begin{array}{l}\vec{j} \\
\text { d. }\end{array}$ & 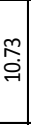 & $\begin{array}{l}0 \\
\dot{\theta} \\
-\end{array}$ & $\begin{array}{l}0 \\
0 \\
0\end{array}$ & 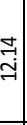 & \begin{tabular}{c}
$\infty$ \\
\hdashline \\
\hdashline
\end{tabular} & & & & & & $\begin{array}{l}\text { g. } \\
\text { - }\end{array}$ & & 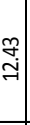 & 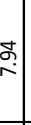 & & & \\
\hline & & & $\Rightarrow \stackrel{\infty}{\infty}$ & -1 & $\exists$ & $\exists$ & & $\simeq$ & $\Rightarrow$ & $\stackrel{\infty}{-1}$ & $\exists$ & $\exists$ & & & 9 & 9 & $\Rightarrow$ & $\approx$ & & & 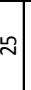 & & & \\
\hline & 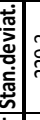 & ন্ & 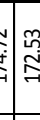 & & 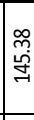 & 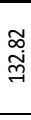 & & 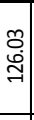 & 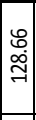 & 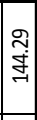 & :ִ. & 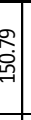 & & & 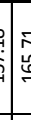 & 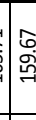 & $\begin{array}{l}\vec{b} \\
\vec{\exists} \\
\vec{\exists}\end{array}$ & 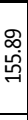 & & & 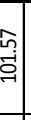 & 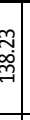 & & \\
\hline & 㲾 & & & & & & & & ભ̆ & & & & & & & $\stackrel{乛}{\Im}$ & & & & & & & & \\
\hline
\end{tabular}

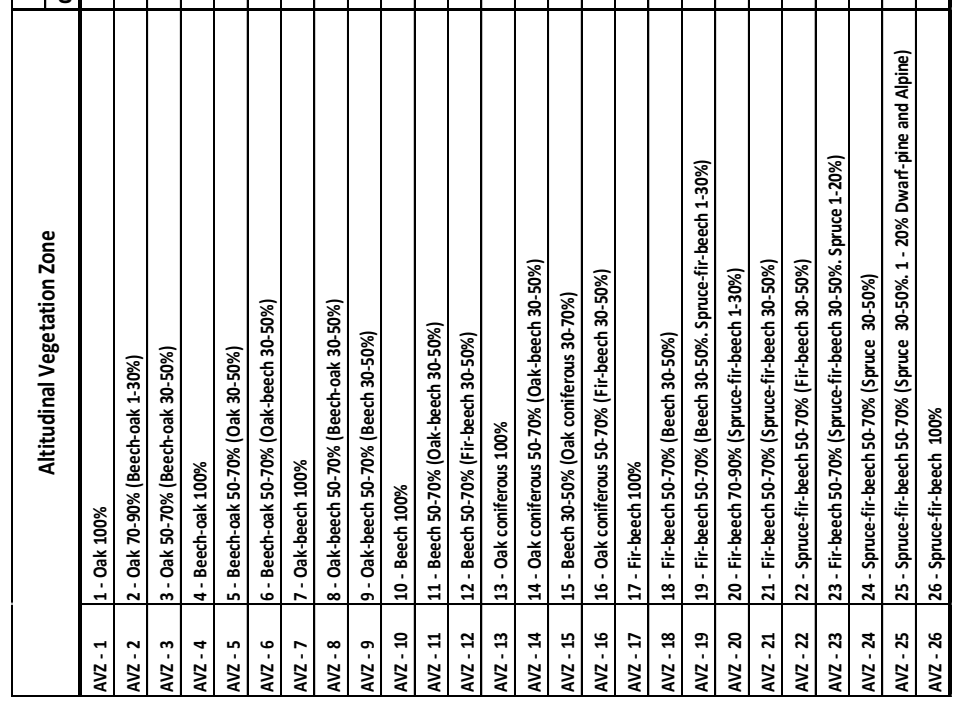


Individuals in higher altitudinal vegetation zones, from the Oak-Coniferous altitudinal vegetation zone (AVZ 14) succeed in reaching the largest mean girth and height. Trees on the transition between the Oak (AVZ 3), Oak-Coniferous (AVZ 14) and Fir-Beech (AVZ 23) altitudinal vegetation zones reach the highest mean age (Tab. 4).

European ash (Fraxinus excelsior) reaches the greatest range of occurrence of all memorial trees from the Oak-Beech (AVZ 7) up to the Fir-Beech (AVZ 17) altitudinal vegetation zones. Of other species, a similar range of occurrence have smooth elm (Ulmus minor) (AVZ 7-AVZ 16) and Norway maple (Acer platanoides) (AVZ 9-AVZ 17). Visible is the boundary of the occurrence of lowland species and species growing in higher elevations, e.g. representatives of field maple (Acer campestre), sycamore maple (Ulmus glabra) or silver fir (Abies alba).

The lowest variability of the occurrence in altitudinal vegetation zones is that of European hornbeam (Carpinus betulus) and sessile oak (Quercus petraea). European hornbeam (Carpinus betulus) is proclaimed a memorial tree only in the Beech altitudinal vegetation zone (AVZ 10-AVZ 12). Registered representatives of sessile oak (Quercus petraea) occur on the transition between the Oak-Beech and Beech altitudinal vegetation zones (AVZ 9-AVZ 11) (Fig. 4).

Fig. 4: Representation of some tree species in altitudinal vegetation zones

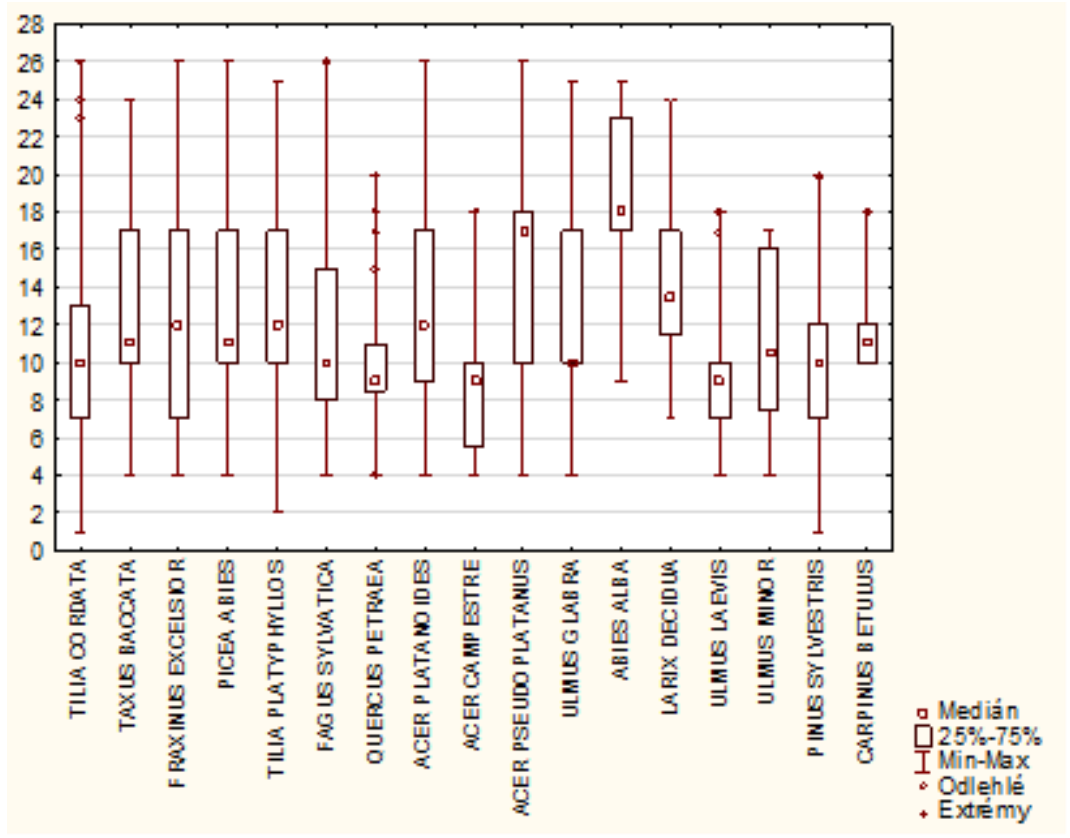

Based on the average values of growth characteristics, we can state that the best doing in terms of the greatest mean girth are individuals of large-leaved linden (Tilia platyphyllos) in cadastral areas predominated by the Spruce-Fir-Beech altitudinal vegetation zone (AVZ 22).

Individuals of Norway spruce (Picea abies) and silver fir (Abies alba) reach the greatest mean height in cadastral areas predominated by the Fir-Beech (AVZ 23) altitudinal vegetation zone. The AVZ 23 coding unit features also memorial trees with the average highest age thanks to large-leaved linden (Tilia platyphyllos, 405 years) and common yew (Taxus baccata, 400 years) (Tab. 5). 
Table 5: The highest mean growth characteristics and age of some tree species in altitudinal vegetation zones

\begin{tabular}{|l|c|c|c|c|c|c|}
\hline \multicolumn{1}{|c|}{ SPECIES } & $\begin{array}{c}\text { Altitudinal } \\
\text { Vegetation } \\
\text { Zone (AVZ) }\end{array}$ & $\begin{array}{c}\text { GIRT - } \\
\text { diameter } \\
\text { (cm) }\end{array}$ & $\begin{array}{c}\text { Altitudinal } \\
\text { Vegetation } \\
\text { Zone (AVZ) }\end{array}$ & $\begin{array}{c}\text { HEIGHT - } \\
\text { diameter } \\
\text { (m) }\end{array}$ & $\begin{array}{c}\text { Altitudinal } \\
\text { Vegetation } \\
\text { Zone (AVZ) }\end{array}$ & $\begin{array}{c}\text { AGE - } \\
\text { diameter } \\
\text { (years) }\end{array}$ \\
\hline ABIES ALBA & 24 & 306 & 23 & 42 & 24 & 195 \\
\hline ACER CAMPESTRE & 18 & 313 & 23 & 27 & 9 & 221 \\
\hline ACER PLATANOIDES & 26 & 446 & 9 & 25 & 9 & 153 \\
\hline ACER PSEUDOPLATANUS & 23 & 475 & 9 & 35 & 23 & 275 \\
\hline CARPINUS BETULUS & 10 & 291 & 10 & 17 & 10 & 205 \\
\hline FAGUS SYLVATICA & 23 & 511 & 23 & 27 & 24 & 258 \\
\hline FRAXINUS EXCELSIOR & 15 & 477 & 9 & 28 & 15 & 273 \\
\hline LARIX DECIDUA & 20 & 455 & 12 & 30 & 15 & 135 \\
\hline PICEA ABIES & 21 & 427 & 18 & 46 & 24 & 270 \\
\hline PINUS SYLVESTRIS & 15 & 331 & 15 & 18 & 4 & 228 \\
\hline QUERCUS PETRAEA & 11 & 435 & 7 & 24 & 10 & 226 \\
\hline TAXUS BACCATA & 9 & 306 & 19 & 13 & 23 & 400 \\
\hline TILIA CORDATA & 26 & 572 & 26 & 28 & 22 & 283 \\
\hline TILIA PLATYPHYLLOS & 25 & 645 & 19 & 30 & 23 & 404 \\
\hline ULMUS GLABRA & 18 & 512 & 17 & 40 & 18 & 250 \\
\hline ULMUS LAEVIS & 11 & 348 & 9 & 35 & 9 & 100 \\
\hline ULMUS MINOR & 506 & 17 & 27 & 8 & 200 \\
\hline
\end{tabular}

Occurrence of memorial trees in the units of biogeographical division (Culek et. al., 1996)

By combining the above mentioned two databases, the Biogeographical Registry and the AOPK CR database of memorial trees, the information about the memorial trees could be extended to include data on the abundance of individual tree species and species diversity of memorial trees in the individual units of Biogeographical division of the Czech Republic (Culek et. al., 1996). From the biogeographical point of view, the Czech Republic belongs in the biome of deciduous broadleaved forests (Hendrych, 1984), which is divided into two biogeographical provinces - Pannonian and that of Central European deciduous forests.

To the date of 31 December 2006, i.e. to the date of the last update of the used AOPK CR database of memorial trees, there were only 187 memorial trees (in 44 items) of 12 species (5 allochthonous) belonging in the Pannonian province in the Czech territory with one distinguished North-Pannonian subprovince. The most abundant tree species are pedunculate oak (Quercus robur) and small-leaved linden (Tilia cordata). Memorial trees with the largest girth are pedunculate oak (Quercus robur) with $710 \mathrm{~cm}$ and London plane (Platanus $x$ acerifolia) with $696 \mathrm{~cm}$, the height of which $(41 \mathrm{~m})$ ranks the latter also to the tallest trees in this province. The age of trees ranges from $100-900$ years, the oldest specimens being a 900-year old large-leaved linden (Tilia platyphyllos) and a 450-year old pedunculate oak (Quercus robur).

A majority of memorial trees, i.e. 26,075 individuals (107 species, hybrids and cultivars, of which 52 allochthonous species) falls in the province of Central European deciduous forests. The province is further divided into 3 subprovinces: Hercynian subprovince with 12 species, hybrids and cultivars (23,614 individuals), Polonian subprovince with 22 species (140 
individuals) and West-Carpathian subprovince with 45 species (2,319 individuals). The species most represented in all subprovinces are once again individuals of small-leaved linden (Tilia cordata) and pedunculate oak (Quercus robur).

As to girth, the most monumental in the Hercynian subprovince are individuals of large-leaved linden (Tilia platyphyllos) with $1,225 \mathrm{~cm}$ and $1,150 \mathrm{~cm}$ or a small-leaved linden (Tilia cordata) with $1,122 \mathrm{~cm}$ and a pedunculate oak (Quercus robur) with $1,003 \mathrm{~cm}$. In the Polonian subprovince, an individual with the largest girth is a London plane (Platanus $x$ acerifolia) with $790 \mathrm{~cm}$, and in the West-Carpathian subprovince, the most monumental specimens are a sessile oak (Quercus petraea) with $900 \mathrm{~cm}$ and a small-leaved linden (Tilia cordata) with $813 \mathrm{~cm}$.

In the Polonian subprovince, the greatest tree height was recorded in a London plane (Platanus $x$ acerifolia) with $38 \mathrm{~m}$. In the Hercynian subprovince, the tallest trees are conifers - a European larch (Larix decidua) with $58 \mathrm{~m}$ and a silver fir (Abies alba) with $55 \mathrm{~m}$. The tallest trees in the West-Carpathian subprovince are conifers too - a Norway spruce (Picea abies) with $47 \mathrm{~m}$ and a silver fir (Abies alba) with $45 \mathrm{~m}$.

The oldest individuals with an expected age over 1,000 years occur in the Hercynian subprovince - pedunculate oaks (Quercus robur) and large-leaved lindens (Tilia platyphyllos). The oldest individuals in the Polonian subprovince, the age of which is estimated at mere 400 years include a pedunculate oak (Quercus robur) and a small-leaved linden (Tilia cordata). The oldest individual in the West-Carpathian subprovince is a common yew (Taxus baccata) aged approx. 1,000 years.

\section{Bioregions}

The lowest unit distinguished in the above-characterized individual division is a biogeographical region (bioregion). In the Czech Republic, there are 91 bioregions with at least one proclaimed memorial tree. Most individuals are registered in the bioregion of Velké Meziř́íí (5.5\%), in the Šumava bioregion (5.5\%) or for example in the bioregion of Svitavy $(5.2 \%)$. A comprehensive survey of memorial trees in the bioregions with growth characteristics and age is presented in Tab. 6. Representation of individuals recorded in the bioregions is presented also in Map Attachment No. 4. Species diversity of memorial trees in the individual bioregions is presented in Map Attachment No. 5. 
Table 6: Representation of memorial trees in bioregions (above $2 \%$ )

\begin{tabular}{|c|c|c|c|c|c|c|c|c|c|c|c|c|c|c|c|c|c|c|}
\hline \multirow{3}{*}{ 岁 } & 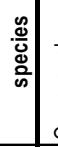 & 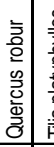 & 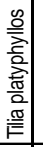 & 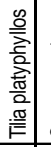 & 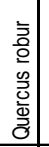 & 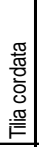 & 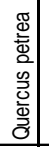 & 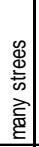 & 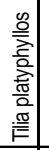 & 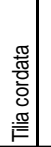 & 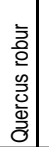 & 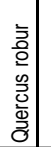 & 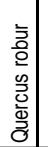 & 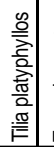 & 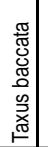 & 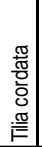 & 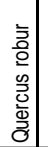 & 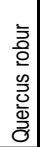 \\
\hline & $\begin{array}{l}\bar{\Phi} \\
\text { 帝 }\end{array}$ & ఏ. & ঃ & ৪ి & 听 & 윰 & ঃ & 이 & প্ব & 응 & 윰 & 유 & శ్యి & 总 & ৪) & o & : & 8 \\
\hline & 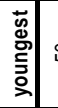 & 8 & ஃ & $\infty$ & 음 & 으 & 웅 & 으 이 & 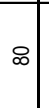 & 응 & 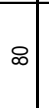 & 으 & ه & ิ & 응 & 8 & $\infty$ & 으 \\
\hline 논 & 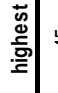 & \& & \& & 8 & $\stackrel{\infty}{\infty}$ & \& & $\stackrel{\infty}{\infty}$ & $\ddot{m}$ & $\forall$ & 9 & ल) & $\mathbb{\infty}$ & $f$ & $\tau$ & ஜี & ᄋ్ల & $\mp$ & $\mathscr{m}$ \\
\hline 岌 & 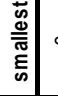 & 0 & 0 & 으 & 이 & 으 & $\wedge$ & क) & $\infty$ & 10 & $\stackrel{m}{-1}$ & $\simeq$ & 으 & \pm & 으 & $\simeq$ & $\sigma$ & $r$ \\
\hline$\frac{\sqrt{\frac{\pi}{5}}}{\bar{\sigma}}$ & 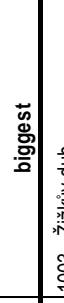 & 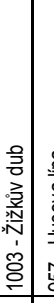 & 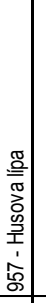 & 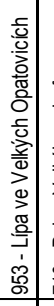 & 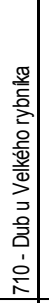 & 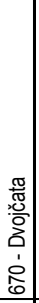 & $\begin{array}{l}0 \\
0 \\
3 \\
0 \\
0 \\
0 \\
\dot{0} \\
\delta \\
8\end{array}$ & 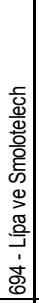 & 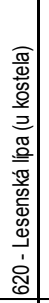 & 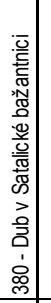 & 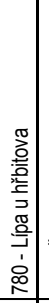 & 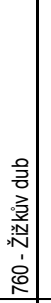 & 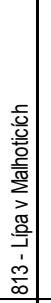 & 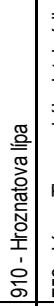 & 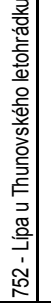 & 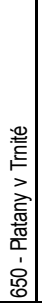 & 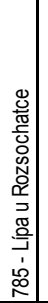 & 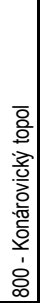 \\
\hline & 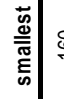 & $\stackrel{\circ}{\circ}$ & 8 & ㅇ & $\cong$ & $\overline{\mathrm{I}}$ & $\stackrel{\text { 另 }}{\sim}$ & $\Phi$ & 음 & $\cong$ & 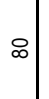 & $\approx$ & $\stackrel{\mathbb{N}}{\sim}$ & $\stackrel{?}{=}$ & $\stackrel{\circ}{=}$ & $\stackrel{m}{=}$ & 8 & จำ \\
\hline $\begin{array}{l}\frac{n}{2} \\
\frac{1}{2}\end{array}$ & 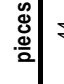 & 7 & \& & is & థ్ల & 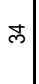 & $\approx$ & (5) & $\simeq$ & $\varnothing$ & $\simeq$ & $\stackrel{\sim}{ \pm}$ & $\approx$ & 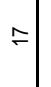 & $\stackrel{0}{=}$ & $m$ & $\hat{m}$ & $\bar{f}$ \\
\hline 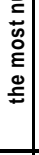 & $\begin{array}{ll} \\
\frac{2}{0} \\
\text { के } \\
\text { के }\end{array}$ & 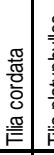 & 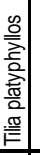 & 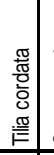 & 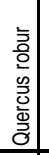 & $\begin{array}{l}\text { ㄱ. } \\
0 \\
0 \\
0 \\
\overline{0} \\
0 \\
0 \\
3\end{array}$ & 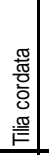 & 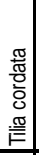 & 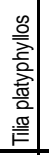 & 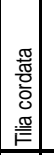 & 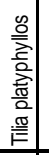 & 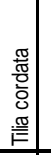 & 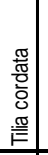 & 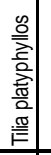 & 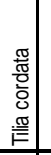 & 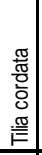 & 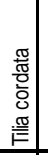 & 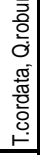 \\
\hline 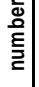 & 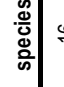 & 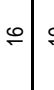 & 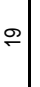 & $\stackrel{d}{\sim}$ & $\stackrel{\oplus}{\square}$ & 으 & ని & $\stackrel{2}{2}$ & का & $\stackrel{\infty}{\sim}$ & 으 & 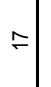 & $\bar{\sim}$ & $\simeq$ & $\stackrel{\sim}{\sim}$ & $\simeq$ & $\stackrel{20}{\square}$ & $\stackrel{\infty}{N}$ \\
\hline 壳 & $\therefore$ & 吕 & مْ & กิ & 官 & 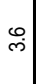 & 岕 & $\stackrel{m}{p}$ & 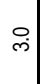 & $\mid \begin{array}{c}0 \\
\dot{m}\end{array}$ & $\stackrel{\bullet}{\sim}$ & $\stackrel{\sim}{\sim}$ & $\stackrel{\sim}{N}$ & $\stackrel{m}{\sim}$ & $\stackrel{m}{\sim}$ & $\widetilde{\sim}$ & $\approx$ & 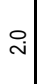 \\
\hline 을 & & 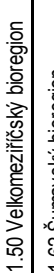 & 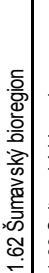 & 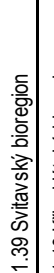 & 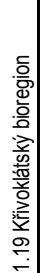 & 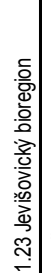 & 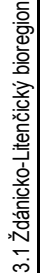 & 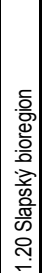 & 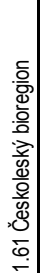 & 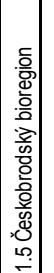 & 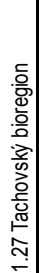 & 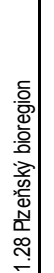 & 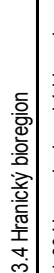 & 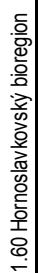 & 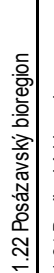 & 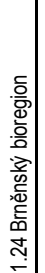 & 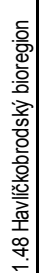 & 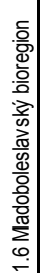 \\
\hline
\end{tabular}




\section{DISCUSSION}

Reasons for many important trees having been preserved in the territory of the Czech Republic should be searched in the history and development of the country, in which a close relationship between humans and trees has been established since the times immemorial. Already the old Slavonic nations believed that trees possess divine power and this is why they were considered sacred (Martičko et al., 2010). Since those times, many customs and traditions have been preserved related not only to trees but also to their planting (upon the birth of son, building of a house and also on various important events). In the past times, these trees were of symbolic character, could not be cut and usually reached a very high age (Hrušková \& Ludvík, 2006). This closely relates to places where we find the monumental and memorial trees today most frequently. As a rule, they accompany historical buildings (castle, mansion, church), or they grow as solitaires in the landscape or in the forest as the remnants of ancient trails or land boundaries (Chadt, 1913). Another possibility for the occurrence of memorial trees is within the formations of varying size such as alleys or remainders of primeval forests. This is the conception on which the division of registered items of memorial trees in the AOPK CR database dwells. Most memorial trees occur in line formations and in the category of tree group $(29.8 \%)$. The category of solitaires includes $13.47 \%$ of memorial trees, and only $0.74 \%$ of memorial trees occur within a forest stand.

\section{Growth characteristics of memorial trees}

The ascertained and evaluated data on memorial trees in the Czech Republic are compared in the following chapter with other available sources dealing with monumental and memorial trees in our territory.

An extensive group of publications on monumental and memorial trees we used to compare with the AOPK CR database consists of manuals dealing with the memorial trees at a regional level (Modrý, 2004; Kubačka \& Kubáčková, 2005; Hrubá \& Valentová, 2005; Hrušková, 2008; Gergel et. al., 2004; Koutník, 1997; Doneeová \& Janočko, 2003; Michálek, 2008; 2006; Dundychová, 1994; Tábor et. al., 2005; Taraba \& Navrátilová, 2005; Kovařík et. al., 1996). A majority of trees mentioned in these publications do not surpass by their growth the most monumental representatives of the species included in the AOPK CR database. These manuals usually build on the AOPK CR database, and only very exceptionally mention other trees important for a specific region or district, which may overreach the size of memorial trees from the AOPK CR database. For example, in the region of Ústí nad Labem, an individual of elm (Ulmus sp.) allegedly occurs according to Vykouk \& Keller (2009), which is larger than the elm tree included in the database from 2006, with a girth of $456 \mathrm{~cm}$. In the Olomouc region, a European white elm (Ulmus leavis) was recently found with a girth of $660 \mathrm{~cm}$, which would indicate that it is a new largest representative of the species in our country (Olomouc, 2006). These exceptions show that new giant trees can still be found.

The most abundant species of memorial trees are oaks (Quercus robur, $15 \%$ ) and limes (Tilia cordata, 34 \%, Tilia platyphyllos, $7 \%$ ) (Tábor, 1998; 2001; 2002; 2003; 2004; 2005; Kyzlík, 2009; Kender et. al,. 2005). A similar species composition of memorial trees was mentioned already by Chadt (1913), who mentions 115 lime trees and 56 oaks in his book.

According to the AOPK CR database of memorial trees, the most monumental trees are two large-leaved lindens (Tilia platyphyllos) - the so-called Vejdova linden at Pastviny with a girth of $12,25 \mathrm{~m}$ and the Sudslavická linden with a girth of $11,50 \mathrm{~cm}$. Other giant trees are represented by the Tatrovická linden (Tilia cordata) with 11,22 $\mathrm{m}$ near Tatrovice in the Sokolov district, and Žižka's oak (Quercus robur) with 10,03 m in Náměšt' nad Oslavou (Tábor et. al., 1998; 2001; 2002; 2003; 2004; 2005; Kyzlík, 2009; Kender et. al, 2005). Chadt 
(1913) informs that the most monumental tree at his time was a black poplar (Populus nigra) with a girth of $15,71 \mathrm{~m}$ (in Lochovice) and lindens (Tilia sp.) with girths $14 \mathrm{~m}$ or 12,56 m. According to Chadt (1913), the most monumental of oaks was a sessile oak (Quercus petraea) with a girth of $12,30 \mathrm{~m}$. Worth mentioning is also the girth of white poplar (Populus alba) reaching $9,73 \mathrm{~m}$. According to Heike $(1984,1985)$, we can find monumental trees also in castle parks and palace gardens; however, they are smaller as compared with the AOPK CR database of memorial trees.

The age of memorial trees is often overestimated, especially in the mentioned oldest specimens (Hartesveldt et al., 1975; Kyzlík, 2009). The AOPK CR database of memorial trees claims that the age of several oldest specimens is assumed over a thousand years. These include three individuals of pedunculate oak (Quercus robur) - Körner's oak at Dalovice, Oldřich's oak in Peruce and Žižka's oak near Třebíč, two individuals of large-leaved linden (Tilia platyphyllos) - the Klokočovská linden near Klokočov, the Vlásenická (Holub's) linden near the village of Jistebnice, and a common yew (Taxus baccata), also called Tisíciletý (Thousand-year old) yew in Žilina near Nový Jičín. The actual age cannot be verified due to its poor health condition and rotten centre of the trunk and this is why the authors differ in the data. Chadt (1913) informs that the oldest trees in the Lands of the Bohemian Crown were yews (Taxus baccata), namely a yew at Macocha, the age of which was according to the annual rings 2,000 years, and a still living yew near Pernštejn, which is allegedly up to 2,000 years old. However, Chadt (1913) identifies with the view that oaks and lindens are species that can live up to $1,000-1,500$ years, according to tree age verified by summing up annual rings or from historical books or chronicles.

There is no doubt that all massive important trees have not been found yet in our territory and a possibility still exists of striking interesting specimens during terrain reconnaissance. An illustrative example of this can be the private tally of significant trees in the Blansko district made by Kala (2007), in which the author mentions monumental specimens of e.g. European hornbeam (Carpinus betulus, $340 \mathrm{~cm}$ ) or Weymouth pine (Pinus strobus, $424 \mathrm{~cm}$ ), with dimensions exceeding those of individuals in the AOPK CR database of memorial trees. Results of inventory in the territory of Soutok show, too, that trees larger than those so far registered in the AOPK CR database can still be found, which is for example documented by a field maple (Acer campestre, $504 \mathrm{~cm}$ ) (Maděra et. al., 2006; 2008).

In 2003 - 2004, Lesy České republiky (Forests of the Czech Republic), s.p. (LČR) carried out mapping of memorial trees in the territory managed by the company. Recorded were 308 individuals and groups of "Important Trees of LČR", which were introduced into the corporate database and designated in the field with uniform information panels. One of the most monumental trees is a small-leaved linden (Tilia cordata) with a girth of $1,425 \mathrm{~cm}$. This means that the specimen is the largest one in the Czech Republic. Height data of specimens in the LČR database do not markedly differ from the standard tree height range of the given species (Významné stromy LČR, 2010). Vojenské lesy a statky ČR (Military Forests and Farms of the Czech Republic) - VLS responded in 2005 by creating their own database of important trees occurring in the territory under their management. The VLS database currently includes 428 individuals of 22 species. Recorded values of important VLS trees as a rule do not reach dimensions of the same species in the AOPK CR database. A monumental tree worth mentioning is a small-leaved linden (Tilia cordata) with a girth of $853 \mathrm{~cm}$, and species that are up to or slightly surpass individuals from the AOPK CR database are represented by a white willow (Salix alba) with $713 \mathrm{~cm}$ or a European mountain ash (Sorbus aucuparia) with 157 cm (Významné stromy VLS ČR, 2010). 
Comparing the achieved growth characteristics of memorial trees with data published in the Czech Republic

To be complete, we compared the highest values of growth characteristics in memorial trees with data in dendrological publications (Červenka \& Cigánova, 1989; Böhm, 1985; Fér \& Pokorný, 1964; Čabart, 1988; Kavka, 1995; Úradníček \& Maděra et. al., 2001; Svoboda, 1953 - 1957; Musil \& Hamerník, 2007; Hejný \& Slavík, 2003).

Results of the comparison showed that in girth parameters, ca. $25 \%$ of memorial trees surpass dimensions commonly given for the species. As a rule, the traditional girth dimensions are by $1.1-2.6$ times greater. Species most exceeding the average girth quoted in the above publications are sessile oak (Quercus petreae) (Hejný \& Slavík, 2003) and whitebeam (Sorbus aria) (Úradníček \& Chmelař, 1995). In addition to the monumental lime trees and pedunculate oaks, another species exceeding its usual girth parameters is black alder (Alnus glutinosa), which -according to Úradníček et. al. (2001) usually reaches 350 $\mathrm{cm}$ - has respectable $635 \mathrm{~cm}$ in the database. Worth mentioning is also the girth of wild cornel (Cornus mas), the girth of which is - instead of usual $150 \mathrm{~cm}$ (Úradníček \& Maděra et. al., 2001) - rare $225 \mathrm{~cm}$ in the AOPK CR database of memorial trees.

Representatives of species that are allochthonous in the Czech territory do not markedly exceed their usual girth parameters or such cases are rare. For example, very well doing is Austrian pine (Pinus nigra), which has reached $376 \mathrm{~cm}$ according to the AOPK CR database of memorial trees instead of $320 \mathrm{~cm}$ quoted in the professional publications (Úradníček, \& Chmelař, 1995; Úradníček \& Maděra et. al., 2001). Another example is gingko (Gigno biloba) reaching up to 350-620 cm (Musil \& Hamerník, 2007), which should have up to 420 $\mathrm{cm}$ in girth according to the database. Well off in our conditions is also silver maple (Acer saccharinum), which normally reaches a girth of $350 \mathrm{~cm}$ (Hejný \& Slavík, 2003) and the database of memorial trees contains an individual with $581 \mathrm{~cm}$. A similar case is that of white mulberry (Morus alba) reaching $150 \mathrm{~cm}$ (Úradníček \& Chmelař, 1995), which has a girth of $286 \mathrm{~cm}$ in the database.

As to the tree height, the individuals registered in the AOPK CR database usually do not exceed the values quoted in the professional publications, with no difference to whether the species is autochthonous or allochthonous (Hurych, 1996; Červenka \& Cigánova, 1989; Pilát, 1953; Větvička, 1984; Kremer, 1995; Bauer, 1989; Anonymus, 1990; Zelený, 1990; Aas \& Riedmiller, 1994; Mikula, 1976; Fér \& Pokorný, 1964; Wágner \& Ždárský, 1999; Koblížek, 2000; Čabart, 1988; Kavka, 1995; Mikula \& Vanke, 1989; Úradníček \& Chmelař, 1995; Musil \& Hamerník, 2007; Hejný \& Slavík, 2003). Exceptions are only oleaster (Eleagnus angustifolia), larches (Larix decidua, Larix kaempferi), black poplar (Populus nigra) and common pear (Pyrus communis), which surpass the published values by 5-10 $\mathrm{m}$.

\section{Comparing the ascertained data on memorial trees in the Czech Republic with the foreign data}

Girth characteristics gauged in memorial trees in the Czech Republic can be for interest compared with available growth data on trees from abroad, e.g. with the list Champion Trees of British Islands (Mitchell et al., 1990), list of the oldest German trees (Ullrich et. al., 2009), list of trees in Belgian parks (Baudouin, 1992), list of notable trees of France (Cousseran \& Feterman, 2009), list of Natural monuments of Poland (Drzewa pomnikowe, 1962-1999) or with the list of important trees of Italy (Cagnoni, 2005), U.S.A. (American Forests, 2004) and Slovak Republic (Kollár \& Ondrejka, 2008). It is obvious that several representatives from the AOPK CR database can boldly equal the giant trees registered abroad. Individuals surpassing other giants in Europe are maples (Acer campestre, $470 \mathrm{~cm}$, A. platanoides, 530 $\mathrm{cm}$, A. pseudoplatanus, $808 \mathrm{~cm}$ ), black alder (Alnus glutinosa, $635 \mathrm{~cm}$ ), narrow-leaved ash 
(Faxinus angustifolia, $660 \mathrm{~cm}$ ), white poplar (Populus alba, $728 \mathrm{~cm}$ ), brittle willow (Salix fragilis, $545 \mathrm{~cm}$ ), common pear (Pyrus communis, $435 \mathrm{~cm}$ ), mahaleb cherry (Prunus mahaleb, $360 \mathrm{~cm}$ ) and elms (Ulmus glabra, $708 \mathrm{~cm}$ and Ulmus minor, $641 \mathrm{~cm}$ ). The largest girth of all conifers is that of Norway spruce (Picea abies, $520 \mathrm{~cm}$ ). Another tree species occurring at the upper limit of tree dimensions is black poplar (Populus nigra, $800 \mathrm{~cm}$ ), which loses only $25 \mathrm{~cm}$ on the largest poplar from Italy.

According to the Guinness Book of Records, one of the most monumental trees in Europe is a sweet chestnut (Castanea sativa) in Sicily with a girth of $57.9 \mathrm{~m}$ and height $21 \mathrm{~m}$. The individual consists of three parts and its largest part has a girth of respectable $22 \mathrm{~m}$. Its name "Chestnut for one hundred horses" is derived from a $16^{\text {th }}$ century legend. Furthermore, the most monumental representative of large-leaved linden (Tilia platyphyllos) occurs in Germany, with an unbelievable girth of $1,720 \mathrm{~cm}$ (Ullrich et al., 2009), which is followed by a pedunculate oak (Quercus robur) with a girth of about 1,400 cm in Sweden (Pakenham, 2003) and a sessile oak (Quercus petraea) with 1,260 cm in England (Mitchell et al., 1990). Only several centimetres less has a large-leaved linden (Tilia platyphyllos, 1,252 cm) in the Czech Republic. Other monumental specimens occur again in England - a sweet chestnut (Castanea sativa) with a girth of $1,180 \mathrm{~cm}$ (Mitchell et al., 1990), and in Germany a pedunculate oak (Quercus robur) with a girth of $1,178 \mathrm{~cm}$ and a northern red oak (Quercus rubra) with 1,125 cm (Ullrich et al., 2009). Remaining individuals surpassing $10 \mathrm{~m}$ in girth are represented by a small-leaved linden (Tilia cordata) from the AOPK CR Czech database of memorial trees with a girth of $1,122 \mathrm{~cm}$ and a common yew (Taxus baccata) with a girth of $1,073 \mathrm{~cm}$ from England.

According to Chadt (1913), the most monumental individuals in Europe were in the past a common yew (Taxus baccata) in England with a girth of $1,800 \mathrm{~cm}$, an elm (Ulmus sp.) with a girth of , $1668 \mathrm{~cm}$ in Switzerland, a large-leaved linden (Tilia platyphyllos) with a girth over $1,600 \mathrm{~cm}$ in Bavaria, and oaks (Quercus sp.) with girths $1,486 \mathrm{~cm}$ and $1,340 \mathrm{~cm}$ in England. Chadt (1913) also claims that at that time, the most monumental specimen in our country was a black poplar (Populus nigra, 1,571 cm) and informs that already at that time, many other most monumental trees in central Europe occurred in the Lands of the Bohemian Crown. These included the most monumental sessile oak (Quercus petraea) with a girth of $1,230 \mathrm{~cm}$, a large-leaved linden (Tilia plathyphyllos, 1,400 cm) and a small-leaved linden (Tilia cordata, $1,100 \mathrm{~cm}$ ) or a white poplar (Populus alba, $973 \mathrm{~cm}$ ).

The following table (Tab. 7) presents aggregative basic data on the most monumental and oldest individuals in European countries obtained from available sources. Dominating species are once again the representatives of pedunculate oak (Quercus robur) and large-leaved linden (Tilia platyphyllos). 
Table 7: The most monumental and oldest trees in Europe

\begin{tabular}{|l|c|c|c|c|}
\hline \multirow{2}{*}{ STATE } & \multicolumn{2}{c|}{ the oldest tree } & \multicolumn{2}{c|}{ the largest tree } \\
\cline { 2 - 5 } & species & age & species & girt/cm \\
\hline England & Quercus petraea & 1100 & Quercus robur & 1316 \\
\hline Germany & Quercus robur & 850 & Tilia platyphyllos & 1720 \\
\hline Czech republic & Quercus robur & 1000 & Tilia platyphyllos & 1252 \\
\hline Netherlands & Quercus robur & 1000 & Quercus robur & 1000 \\
\hline Belgium & $*$ & $*$ & Quercus robur & 995 \\
\hline Poland & $*$ & $*$ & Quercus robur & 992 \\
\hline Spain & Pinus canariensis & 1000 & Eucalyptus globulus & 1375 \\
\hline France & $*$ & $*$ & Sequoiadendron giganteum & 1260 \\
\hline Slovakai & Tilia platyphyllos & 700 & Tilia platyphyllos & 1100 \\
\hline Italy & Olea europea & 3800 & Castanea sativa & 2200 \\
\hline
\end{tabular}

In the AOPK CR database of memorial trees, the age of several specimens is assumed up to a thousand years, especially if the data have been taken over from various legends and chronicles (Hrušková \& Turek, 1986; 1995; 1999; 2001; 2005). In central Europe, old trees usually reach an age of 300-600 years (Hejný \& Slavík, 2003; Úradníček et al., 2001; Kavka, 1995), although some individuals are supposed to be up to a thousand years old (Kavka, 1995; Mikula \& Vanke, 1989). The hitherto published available data about the maximum age of individual tree species have been aggregated for interest only (Větvička, 1984; Mikula, 1976; Fér \& Pokorný, 1964; Čabart, 1988; Kavka, 1995; Mikula \& Vanke, 1989; Úradníček \& Chmelař, 1995; Úradníček \& Maděra et. al., 2001; Svoboda, 1953-1957; Musil \& Hamerník, 2007; Hejný \& Slavík, 2003). The available data on the age of memorial trees, which are usually based on the estimate of surveyors, correspond to the published values. The only exception is a European ash (Fraxinus excelsior) aged 400 years, which can reach only 200 - 250 years according to Kavka (1995), Čabart (1988), or a black poplar (Populus nigra) whose age is allegedly 400 years although it can normally reach only 200 years (Kavka, 1995; Cabart, 1988). Worth mentioning is also the registration of up to 300-year old wild service trees (Sorbus torminalis) and service trees (Sorbus domestica) although their individuals usually reach only a half of the age (Kavka, 1995; Mikula \& Vanke, 1989).

Data on the most monumental individuals contained in the LČR and VLS databases are based on estimates (Významné stromy VLS ČR, 2010; Významné stromy LČR, 2010). Nevertheless, the age of newly entered individuals is recorded according to stock maps and registration sheets, which represent creditable guidelines to determine the age of other trees in the future.

Unfortunately, the data from European databases are not complete either, and therefore cannot be objectively evaluated. According to a research study conducted at the University in Ulmea, the oldest tree in Europe was determined a Norway spruce (Picea abies) in Sweden, for which the age of roots was determined to be 9,550 years. Since it is a clone, the age of its trunk is estimated at 600 years (Kullman, 2008). The other oldest European species are representatives of common yew (Taxus baccata), for which it was demonstrated that they can live up to 4,000 years in England (Billing, 2004) or Bosnian pine (Pinus leucodermis, 1,270 years - Italy, 1,300 years - Bulgaria) and European larch (Larix decidua) with 2,085 years (Pakenham, 2003). Tree species that may rank with the oldest ones are common fig (Ficus sp. - Spain), chestnut (Castanea sativa, 3,000 years - Italy), olive trees (Olea europaea, 3,000 let 
- Italy, 2,800 years - Portugal) or pears (Pyrus communis) since they represent trees humans have been using for their own benefit for over 2,000 years (Noris, 2011).

The oldest clone in the world is mentioned to be a quaking aspen (Populus tremuloides, so-called Pando), which is $80,000-1$ million years old. It is at the same time considered one of the heaviest organisms in the world (6,000 tons) (Mitton \& Grant, 1996). Until recently, the oldest tree in the world was considered a bristlecone pine (Pinus longaeva, so-called Prometheus) with an age estimated at 4,862 years; unfortunately, it was felled by accident in 1964. Its place has been taken by another bristlecone pine (Pinus longaeva, so-called Methusalah), the age of which was set for 4,842 years. The two individuals were to be or may be seen in California, U.S.A. (Rocky Mountain Tree-Ring Research, 2011).

\section{ASSESSMENT ACCORDING TO THE BIOGEOGRAPHICAL POINT OF VIEW}

Most decreed memorial trees fall in the Beech altitudinal vegetation zone (18.2\%). A great part of them can be found also in the Oak-Beech (17.2\%) and Fir-Beech (12.5\%) altitudinal vegetation zones. This representation of memorial trees in altitudinal vegetation zones copies the AVZ representation in the Czech territory. Apparent is a positive dependence between the representation of memorial trees and the population density in the individual altitudinal vegetation zones (Tab. 8).

Table 8: Representation of altitudinal vegetation zones in the Czech Republic (according to Buček \& Lacina, 2002)

\begin{tabular}{|c|c|c|c|c|c|c|c|}
\hline Altitudinal Vegetation Zone & \multirow{2}{*}{$\begin{array}{c}\text { representation in } \\
\text { the } \mathrm{CZ}(\%)\end{array}$} & \multirow{2}{*}{$\begin{array}{l}\text { fertile } \\
\text { ground }\end{array}$} & \multirow[b]{2}{*}{ forests } & \multirow[b]{2}{*}{ grasslands } & \multirow{2}{*}{$\begin{array}{c}\text { orchards } \\
\text { and } \\
\text { gardens }\end{array}$} & \multirow[b]{2}{*}{ vineyard } & occupancy \\
\hline (Zlatník, 1978) & & & & & & & $\begin{array}{c}\text { (population/ } \\
\mathrm{km}^{2} \text { ) }\end{array}$ \\
\hline 1. Oak V.Z. & 3 & 62 & 13 & 2,7 & 4 & 4 & 130 \\
\hline 2. Beech-oak V.Z. & 12 & 61 & 14 & 3 & 4 & 0.5 & 290 \\
\hline 3. Oak-beech V.Z. & 18 & 50 & 25.7 & 7.1 & 3.7 & $*$ & 157 \\
\hline 4. Beech V.Z. & 36 & 42 & 33 & 12 & 2.4 & $*$ & 92 \\
\hline 5. Fir-beech V.Z. & 22 & 25 & 48.6 & 15.4 & 1.4 & $*$ & 58 \\
\hline 6. Spruce-fir-beech V.Z. & 2.9 & 1 & 74 & 12 & $*$ & * & 19 \\
\hline 7. Spruce V.Z. & 0.9 & $*$ & 1.69 & $*$ & $*$ & $*$ & $*$ \\
\hline 8. Dwarf Pine V.Z. & 0.1 & $*$ & 0.29 & $*$ & $*$ & $*$ & $*$ \\
\hline 9. Alpine V.Z. & $*$ & $*$ & $*$ & $*$ & $*$ & $*$ & $*$ \\
\hline
\end{tabular}

Having compared the occurrence of memorial trees in the altitudinal vegetation zones with data about altitudinal vegetation zones of the natural occurrence of given species in the Czech Republic (Úradníček \&Maděra et. al., 2009), we can state that $63 \%$ of memorial trees occur beyond their natural occurrence in the AVZ of the concerned species.

Usually the trees occur higher by $1-2$ AVZs. Only in three specimens of memorial trees, we recorded their occurrence in lower altitudinal vegetation zones. For example, a memorial Norway spruce (Picea abies) is recorded as low as in the Oak altitudinal vegetation zone. Of broadleaved tree species, for example, elm tree (Ulmus minor), which is considered a thermophilic species occurring up to the Oak-Beech altitudinal vegetation zone, occurs according to the AOPK CR database as high as in the Beech and even in the Oak-Coniferous altitudinal vegetation zones. Deviation from its natural site can be seen also in a memorial 
individual of European hornbeam (Carpinus betulus), which occurs in the Beech AVZ although its natural occurrence is to be the Oak-Beech AVZ.

The above discrepancies in the occurrence of some tree species as compared with their natural range of occurrence, expressed by the biogeocoenological formula, can be assigned to the chosen basic unit - cadastral area, based on which the data on the altitudinal vegetation zones were combined with the database of Biogeographical Registry. Important is also the human factor and the fact that some species were planted outside their natural sites.

The most abundant species is small-leaved linden (Tilia cordata), which occurs from the Oak to the Fir-Beech altitudinal vegetation zones. Much lower representation has pedunculate oak (Quercus robur) occurring in 5 coding units and large-leaved linden (Tilia platphyllos) occurring in 3 coding units.

Having compared the data on altitudes at which the memorial trees occur with the data in professional publications, we can state that most memorial trees grow within the natural range of their occurrence. Only black poplar (Populus nigra) and pedunculate oak (Quercus robur) were recorded at higher elevations. Black poplar (Populus nigra) was found as high as at $760 \mathrm{~m}$ above sea level while the documented highest altitude of its occurrence (Čabart, 1988) was $600 \mathrm{~m}$ a.s.1. According to the data, pedunculate oak (Quercus robur) occurs as high as at $905 \mathrm{~m}$ a.s.l. Up to the present, the highest altitude at which it was recorded was 800 m a.s.l. (Hejný \& Slavík, 2003). Two species, representatives of memorial trees, i.e. small-leaved linden (Tilia cordata) and European white elm (Ulmus leavis) occur on the boundary of their natural range, too. The elm reaches even slightly beyond the boundary (498 $\mathrm{m}$ a.s.1.) because the highest growing elm is documented from $420 \mathrm{~m}$ a.s.1. (Hejný \& Slavík, 2003). Of conifers, the usual elevation was considerably exceeded by European larch (Larix decidua), in which Musil \& Hamerník (2007) state the greatest occurrence in the Czech Republic at $750 \mathrm{~m}$ a.s.1., while the memorial individual grows at $1,015 \mathrm{~m}$ a.s.l.

Regarding the altitudes, the data could be compared also in the LČR and VLS databases of important trees. According to the LČR, the occurrence of important trees corresponds with the traditional occurrence of native species. In specimens chosen by VLS as significant trees, a number of species grow beyond their usual altitudes. This particularly applies, similarly as in the AOPK CR database of memorial trees, to black poplar (Populus nigra) and pedunculate oak (Quercus robur). VLS surveyors found a black poplar (Populus nigra) at $730 \mathrm{~m}$ a.s.l. and a pedunculate oak (Quercus robur) at $900 \mathrm{~m}$ a.s.1., which documents that the occurrence of tree species proclaimed as memorial trees at higher altitudes is not a coincidence and the species can be found growing actually higher than claimed by available publications (Hejný \& Slavík, 2003; Čabart, 1988). Apart from the above mentioned species, the VLS database contains also European apple (Malus sylvestris), small-leaved linden (Tilia cordata) and wild service tree (Sorbus torminalis) growing at higher than usual elevations.

One of partial benefits of this study is evaluation of the occurrence and abundance of memorial trees in units of biogeographical division of the Czech Republic (Culek et. al., 1996) and further extension of the characteristics of bioregions (Map Appendices Nos. 4, 5).

\section{CONCLUSION}

Important trees can be considered trees that reach high age, unusual size or represent an important part of cultural and historical heritage. We learn about the existence of these important trees either from local people or thanks to inventories focused on such trees (Maděra et. al, 2000; Brzobohatý, 2000; Sedláčková, 2007; Rychtecká, 2004; Dreslerová, 2006; a.o.). The most popular and available at a national level is considered the database of memorial trees of the Czech Republic, which is a part of the Central List of Nature 
Conservation (AOPK CR) and which was provided for a detailed analysis. Based on a combination with another extensive database of Biogeographical Registry, a comprehensive overview was compiled about the current state of memorial trees in relation to biogeographical units (abundance, species composition and maximum growth characteristics). Occurrence of monumental trees and knowledge of the growth parameters of individual species should constitute a part of basic landscape and species characteristics to figure out what maximum growth dimensions the given species can reach in the given site conditions. One of outstanding contributions of this study is the evaluation of the occurrence and abundance of memorial trees according to biogeographical division of the Czech Republic (Culek et. al., 1996) and addition of further data to the characteristics of bioregions.

\section{REFERENCES}

Aas, G., Riedmiller, A., (1994). Kapesní atlas - Stromy. Slovart s r. o., Praha. 156 s.

Alexander, K.N.A., (1998). The links between forest history and biodiversity: the invertebrate fauna of ancient pasture woodland in the British Isles and its conservation. In: Kirby. K. and Watkins, C., The Ecological History of European Forests (pp. 73-80). Wallingford: CABI International.

American Forestry, (2004). National registr of big trees. Retrieved on September 10, 2004 from http://www. americanforestry.org.

Anonymus, (1990). Katalog okrasných dřevin a růži. Martin.

Anonymus, (1998). Comune di fratta polesine norme tecniche di attuazione. Retrieved on March 11, 2011 from http://sit.polesineinnovazione.it/frattapolesine/nta/NTA-PRG.pdf.

Baudoin, J. C., Spoelberch, de Ph., Meulder, van J., Jacobs, R., (1992). Bomen in Belgie. Dendrologische inventaris 1987-1992. Stichting Spoelberch - artois. 511 pp.

Bauer, Z., (1989). Územní systém ekologické stability a zemédělská výroba. Brno.

Billing, J., (2004). North Wales Coast and the Isle of Anglesey. The Hidden Places of Wales (3rd ed.). Travel Publishing. ISBN 9781904434078, pp. 45-92.

Böhm, Č., (1985). Okrasné listnáče našich zahrad. SZN Praha.

Brzobohatý, J., (2000). Ekologicky významné segmenty krajiny pobřežní zóny nivy Dyje v oblasti Soutok. Diplomová práce. MZLU v Brně, Brno.

Buček, A., Lacina, J., (1988). Registr Biogeografie v integrovaném informačním systému o území a jeho využití při geografické diferenciaci stav životního prostředí. In Ungerman J. (ed): Geografie teorie a praxe, svazek 10 (pp. 30-48), Vybrané aspekty geografického hodnocení stavu a vývoje životního prostředí v ČSR, Akademie věd ČR, Brno 1988.

Buček, A., Lacina, J., (2002). Geobiocenologie II. Mendlovy zemědělské a lesnické univerzity v Brně, Brno.

Buček, A., Lacina, J., Lacinová, Y., (1992). Návrh jednotné soustavy biogeografických jednotek vymezení v rámci ČSFR provincií, podprovincií a definování regiónů. Obnova ekologické stability krajiny. Projekt ze Státního fondu životního prostředí. Ústav pro životní prostředí Brno.

Butler, J., Rose, F., Green, T., (2001). Ancient trees, icons of our most important wooded landscapes in Europe, Europe's woodland heritage, Tools for preserving woodland biodiversity, Naconex. 
Cagnoni, C., (2005). Grandi alberi d'italia, Alla scoperta dei monumenti naturali del nostro paese, De Agostini Novara, Corpo Forestale dello Stato, ISBN 8841826967, p. 192.

Circulaire ministérielle, (2008). Circulaire ministérielle du 14/11/2008. Retrieved on March 4, 2011 from http://environnement.wallonie.be/dnf/arbres_remarquables/Circulaire_ 14112008.pdf.

Cottrell, J.E., Munro, R.C., Tabbener, H.E., Gillies, A.C.M., Forrest, G.I., Deans, J.D., Lowe, A.J., (2002). Distribution of chloroplast DNA variation in British oaks $(Q$. robur and $Q$. petraea): the influence of postglacial colonisation and human management. For. Ecol. Manage. 156, pp. 181-195.

Cousseran, F., Feterman, G., (2009). Guide des arbres remarquables de France, Associons Arbes, ISBN 2744908215, str. 239.

Culek, M. (1996). Biogeografické členěni České republiky. Praha: Enigma, 1996, 347 s.

Čabart, J., (1988). Krajinná ekologie. Používání dřevin v enviromentální praxi. Vysokoškol. Skripta. Př́rodovědecké fakulty KU. Praha.

Červenka, M., Cigánova, K., (1989). Klič k určování dřevin podle pupenů a větviček. SZN Praha.

Domínguez, S. et. al., (2010). Sanidad Vegetal en Árboles Singulares, en Gigantes y ancianos de los bosques españoles, M. de Medio Ambiente, Rural y Marino, (80-95), España CL, $197 \mathrm{pg}$.

Doneeová, H., Janočko, J., (2003). Památné stromy v okrese Jeseník. Město Jeseník. Trifox.

Dreslerová, J., (2005). Krajinně-ekologické hodnocení významných dřevin v západní části CHKO Poodři a jejich management. Diplomová práce. MZLU v Brně, Brno.

Drzewa pomnikowe, (1962-1999). Drzewa pomnikowe Rzeczpospolita Polska. Retrieved on October 11, 2010 from http://www.kp.org.pl/pdf/poradniki/drzewa_pomnikowe .htm.

Dundychová, I., (1996). Památné stromy okresů Havličkiov Brod, Pelhřimov a Jihlava. Český svaz ochránců př́rody Havlíčkův Brod. Tiskárna Ledeč nad Sázavou.

Fér, F., Pokorný, J., (1964). Listnáče lesů a parků. SZN Praha.

Gergel, J., Šámal, V., Albrecht, J., Němcová, Z., (2004). Památné stromy na Českobudějovicku. Vydal odbor ochrany životního prostředí Magistrátu města Č. Budějovice. Protisk. ISBN 80-239-3389-2.

Hageneder, F., (2003). Velká kniha stromů, Duch stromů. Olomouc: Fontána, 2003. 429 s. ISBN 80-7336-083-7.

Harding, P.T., Wall, T. Eds., (2000). Moccas: an English deer park, Centre for Ecology and Hydrology, English Nature, Peterborough

Hartesveldt, R. J., Harvey, H. T., Shellhammer, S. H., Stecker, R. E., (1975). The giant sequoia of the Sierra Nevada. U.S. Department of the Interior, National Park Service, Washington D.C., Washington, National Park Service.

Heike, K., (1985). Moravské zámecké parky a jejich dřeviny, 1 vydání. Praha: Státní zemědělské nakladatelství. $450 \mathrm{~s}$.

Heike,K., (1984). České zámecké parky a jejich dřeviny. 1vydání. Praha: Státní zemědělské nakladatelství, 1984. $464 \mathrm{~s}$.

Hejný, S., Slavík, B., (2003). Květena ČR - 2. díl, Academia, Praha, ISBN 80-200-1089-0, 15-540, s. 22-24.

Hrubá, D., Valentová, E., (2005). Památné stromy Prostějovska. Příroda Olomouckého kraje 
Hrušková, M., (2008). Za památnými stromy Vysočiny. Nakladatelství MH, Beroun, ISBN 978-8086720-41-8.

Hruškova, M., Ludvík, B., (2006). Pamět’ stromů. 1. vyd. Praha, Mladá fronta, 2006. 260 s. Hrušková, M., Ludvík, B., Turek, J., (2003). Stromy se na nás divají. Fraus, Plzeň.

Hrušková, M., Turek, J., “(1986). O památných stromech, Státní pedagogické nakladatelství Praha, ISBN 14-548-86, s. 192

Hrušková, M., Turek, J., (1995). O památných stromech, Silva Regina, Praha, ISBN 80-902033-0-2.

Hrušková, M., Turek, J., (1999). Stromy pamatují. Praha, s. 42.

Hrušková, M., Turek, J., (2001). Památné stromy II. - vydáno vlastním nákladem, Praha.

Hrušková, M., Turek, J., (2005). Kult stromů v zemích Koruny české, Abonent ND, Praha, ISBN 80-7258-211-9, s. 160.

Hurych, V., (1996). Okrasné dřeviny pro zahrady a parky. Květ-nakladatelství ČZS Plzeň

Chadt, J.E., (1913). Staré a památné stromy v Čechách, na Moravě a ve Slezsku. Vlastním nákladem, Písek.

Kala, F., (2007). Stromy okresu Blansko. Městská knihovna Blansko. Tisk Vladislav Pokorný, Blansko, 102 s.

Kavka, B., (1995). Sadovnická dendrologie 1. Lisnaté stromy. Brno. Acta Pruhonice.

Kender, J., (2005). Památné stromy chráněné státem In: Kender (ed.), Návraty ke stromům, vodě a zemi aneb Deset let péče o krajinu domova. VÚKOZ Průhonice. ISBN 80-85116-41-3.

Kobližek, J., (2000). Jehličnaté a listnaté dřeviny našich zahrad a parků. Tišnov. Sursum. ISBN 80-7323-117-4.

Kollár, D., Ondrejka, K., (2008). Stromy. Prirodné krásy Slovenska. Dahama . ISBN 978-80-89226-62-7, 128 p.

Koutník, J., (1997). Památné stromy na Pelhřimovsku. Nová tiskárna Pelhřimov.

Kovařík, V., Pešout, P., Zelený, V., (1996). Zámecké parky a památné stromy Podblanicka. Český svaz ochránců přírody. Vlaším. ISBN 80-902178-4-2.

Kremer, B.P., (1995). Stromy. Ikar Praha. ISBN 8085830922. 288 p.

Kubačka, M., Kubáčková, M., (2005). Památné stromy Opavska. Průvodce po významných a památných stromech Opavska.

Kyzlík, P., Reš, B., Mračanská, E., (2003). Památné stromy v Čechách, na Moravě, ve Slezsku. Olympia a.s., Praha, ISBN 80-7033-781-8, 244 st.

Mackovčin, P., Sedláček, M. eds., (1999-2007). Chráněná území ČR. Agentura ochrany př́rody a krajiny ČR a EkoCentrum Brno, Praha.

Maděra, P., Buček, A., Štykar, J., Čermák, P., Hrubý, Z., Klečka, J., Král, K., Vojtek, M., (2000). Databank of important tree species in the Odra river watershed riparian zone of streams. Čas. Slez. Muz. Opava (A), 49-2000/3: pp. 239-246.

Maděra, P., Pejchal, M., Dreslerová, J., Krejčiř́ík, P., Klimánek, M., Mikita, T., Lička, D., (2006). Remarkable trees. Dendrological guide to the Dolní Morava Biosphere Reserve. BR Dolní Morava, Břeclav, 51 p.

Maděra, P., Pejchal, M., Úradníček, L., Krejčiřrík, P., Dreslerová, J., Klimánek, M., Mikita, T., Čermák, M., Čížková, L., Lička, D., Čupa, P., (2008). 100 nejzajímavějších stromů 
Biosférické rezervace Dolni Morava. 1. vyd. Olomouc: Machovský, 2008. ISBN 978-80-254-1236-7. $120 \mathrm{~s}$.

Martiško, J., Martičková, K., Martiško, V., (2010). Významné stromy Jihomoravského kraje. EKON. Jihomoravský kraj, 205 s.

Michálek, J., (2005). Přehled základni literatury a dostupných materiáli̊ ke starým a památným stromúm, Retrieved on September 9, 2005 from http://pamatnestromy.cz/ zajimavosti-ochrana-v-minulosti.html.

Michálek, J., (2006). Památné stromy Plzeňského kraje. Krajské muzeum Sokolov. 48 s.

Michálek, J., (2008). Památné stromy Karlovarského kraje. Krajské muzeum Karlovarského kraje. ISBN 978-80-86630-15-1.

Mikula, A., (1976). Naše stromy a keře. Mladá fronta. Praha. 149 s.

Mikula, A., Vanke, P., (1989). Plody planých a parkových rostlin. SNP Praha, s. 309.

Mitchell, A. F., Hallet, V. E., White, J. E. J., (1990). Champion trees in the British Isles. Forestry comission, London: HMSO, 3rd ed Field book 10, ISBN 9780117102866. 33 pp.

Mittmannsgruber, W. o.J., (2011). Die Anfänge des vereinsmäßig organisierten Naturschutzes in Österreich sowie die Entwicklung des Öst. bzw. OÖ. Naturschutzbundes. Retrieved on March 21, 2011 from http://www.naturschutzbund-ooe.at/geschichte.

Mitton, J. B., Grant, M. C., (1996). Genetic Variation and the Natural History of Quaking Aspen, BioScience 46 (1): pp. 25-31.

Modrý, M., (2004). Památné stromy Libereckého kraje. Liberecký kraj, resort životního prostředí a zemědělství. ISBN 80-239-3891-6.

Musil, I., Hamerník, J., (2007). Jehličnaté dřeviny: přahled nahosemenných i výtrusných dřevin: Lesnická dendrologie 1. Vyd. 1. Praha: Academia, ISBN 978-802-0015-679. 352 s.

Noris

Olomouc (2006). Památné stromy Olomouckého kraje. Vydal Olomoucký kraj. Oddělení ochrany př́rody Krajského úřadu.

Pakenham, T., (2003). Remarkable trees of the world. Weidenfeld \& Nicolson, 2003, ISBN 9780297843504, p 192.

Pilát, A., (1953). Listnaté stromy a keře našich zahrad a parků. SZN Praha. 1104 s.

READ, 2006

Read, H., (2000). Veteran Trees: A guide to good management. English Nature, The Countryside Agency and English Heritage, Peterborough, 176 p.

Reš, B., (1998). Památné stromy. - Agentura ochrany př́rody a krajiny ČR, Praha.

Reš, B., Štěrba, P., (2010). Památné stromy. Metodika AOPK ČR, Praha.

Rose, F., (1992). Temperate forest management: its effects on bryophytes and lichen floras and habitats. In: J.W Bates, A.M., Farmer, (eds): Bryophytes and Lichens in a Changing Environment. (pp. 211-233).

Rychtecká, P., (2004). Krajině-ekologické hodnocení významných dřevin ve východni části CHKO Poodři a jejich management. Diplomová práce. Ústav lesnické botaniky, dendrologie a typologie, fakulta Mendlovy zemědělské a lesnické univerzity v Brně, Brno.

Sedláčková, M., (2009). Krajinně-ekologické hodnocení významných dřevin CHKO Litovelské Pomoravi a jejich management. Diplomový práce, LDF - Mendelu v Brně, Brno 
Smith, K.W., Burges, D.J., Parks, R.A., (1992). Breeding bird communities of broadleaved plantation and ancient pasture woodlands of the New Forest. Bird Study 39: 13, pp. 21-41.

Svoboda, P., (1953 - 1957). Lesni dřeviny a jejich porosty I - III, SZN, Praha.

Symonides, E., (2007). Ochrona przyrody, Wydawnictwa Uniwersytetu Warszawskiego, str. 372.

Štěpánek, V., (2004). Kulturní osnova krajiny, Staré cesty a proč je chránit. Veronica 5/2004, Regionální sdružení ČSOP Brno, Brno.

Tábor, I., Reš, B., Součková, M., (1998). Záchrana genofondu památných stromů v Jihočeském a Východočeském regionu, Acta Průhoniciana, ISBN 80-85116-18-9, 84 s.

Tábor, I., Reš, B., Součková, M., (2001). Záchrana genofondu památných stromů v západočeském regionu. Acta Průhoniciana. $70 \mathrm{~s}$.

Tábor, I., Reš, B., Součková, M., (2002). Záchrana genofondu památných stromů v severočeském regionu. Acta Průhoniciana 71, Acta Průhoniciana ; 71, ISBN 80-86559-13-0, $60 \mathrm{~s}$.

Tábor, I., Reš, B., Součková, M., (2003). Záchrana genofondu památných stromů v jihomoravském regionu. Acta Průhoniciana 75.

Tábor, I., Reš, B., Součková, M., (2004). Záchrana genofondu památných stromů v severomoravském regionu. Acta Průhoniciana 76.

Tábor, I., Reš, B., Součková, M., (2005). Záchrana genofondu památných stromů ve středočeském regionu. Acta Průhoniciana 78., VÚKOZ Průhonice, ISSN 0374-5651 ; 78/2005, Pelhřimov, 167 s.

Taraba, R., Navrátilova, M., (2005). Památné stromy města Brna. Vydal Odbor životního prostředí Magistrátu města Brna.

Tutela e valorizzazione degli alberi monumentali, (2011). Tutela e valorizzazione degli alberi monumentali. Retrieved on March 6, 2011 from http://www.molisealberi.com/ Documenti/leggereg2005.pdf .

Ullrich, B., Kühn, S., Kühn, U., (2009). Unsere 500 ältesten Bäume: Exklusiv aus dem Deutschen Baumarchiv. BLV Buchverlag GmbH \& Co. KG, München 2009, ISBN 978-3-8354-0376-5.

Úradníček, L., Chmelař, J., (1995). Dendrologie lesnická. 1. vyd. Brno: Mendelova zemědělská a lesnická univerzita, 1995. ISBN 80-715-7162-8.

Úradníček, L., Maděra, P. ed. et. al., (2001). Dřeviny České republiky. Matice lesnická, spol. s. r. o., Písek.

Úradníček, L., Maděra, P., Tichá, S., Koblížek, J., (2009). Dřeviny České republiky. Lesnická práce s.r.o., ISBN 978-80-87154-62-5, 3-367, 76 p.

Ustawa o ochronie przyrody, (2004). Ustawa o ochronie przyrody 5/2004 (Dz.U. z 2009 r. Nr 151, poz. 1220 ze zm.) Retrieved on March 5, 2001 from http://www.infor.pl/dziennik-ustaw/rok,2009/nr,151/poz,1220.html.

Větvička, V., (1984). Stromy a keře. Avnetium Praha.

Vykouk, M., Keller, V., (2009). Památné stromy na Ústecku. Magistrát města Ústí nad Labem - odbor životního prostředí. ISBN 978-80-254-5319-3.

Významné stromy LČR, (2010). Významné stromy LČR - online database. Retrieved on February 12, 2010 from http://www.lesycr.cz/cs/turiste-a-pratele-prirody/lesy-aochrana-prirody/vyzna-mne -stromy-lcr.ep. 
Významné stromy VLS, (2010). Významné stromy VLS - online database. Retrieved on March 10, 2010 from http://www.vls.cz/nase-cinnosti/ochr.prirody/vyznamnestromy.

Wágner, P., Ždárský, M., (1999). Determinace sadovnicky významných dřevin v beslistém stavu. Mělník.

Zákon o ochrane prírody a krajiny SK, (2002). Zákon o ochrane prírody a krajiny, zákon č. 543/2002 Z. z., s účinnost' od 1.1.2003 (\$ 49, chránené stromy), Retrieved on March 4, 2011 from http://zbierka.sk.

Zákon o ochraně přírody a krajiny., (1992). Zákon České národní rady č. 114/1992 Sb. o ochraně př́rody a krajiny, Retrieved on March 5, 2011 from http://zákony.cz.

Zejda, J., (1980). Význam rozptýlených lesů a zelenè. ČSVTS, Brno.

Zelený, V., (1990). Dřeviny areálu VŠZ v Praze. Praha: VŠZ. ISBN 80-213-0033-7. 119 s.

Zlatník, A., (1973). Základy Ekologie. Praha Státní zemědělské nakladatelství, 1973, 280 s.

ZTV-Baumpflege, (1992). Zusätzliche Technische Vertragsbedingungen und Richtlinien für Baumpflege und Baumsanierung. Forschungsgesellschaft Landschaftsentwicklung Landschaftsbau (FLL), Bonn. 


\section{APPENDIX}

Map. 1: Representation of memorial trees in the Czech Republic in cadastral area
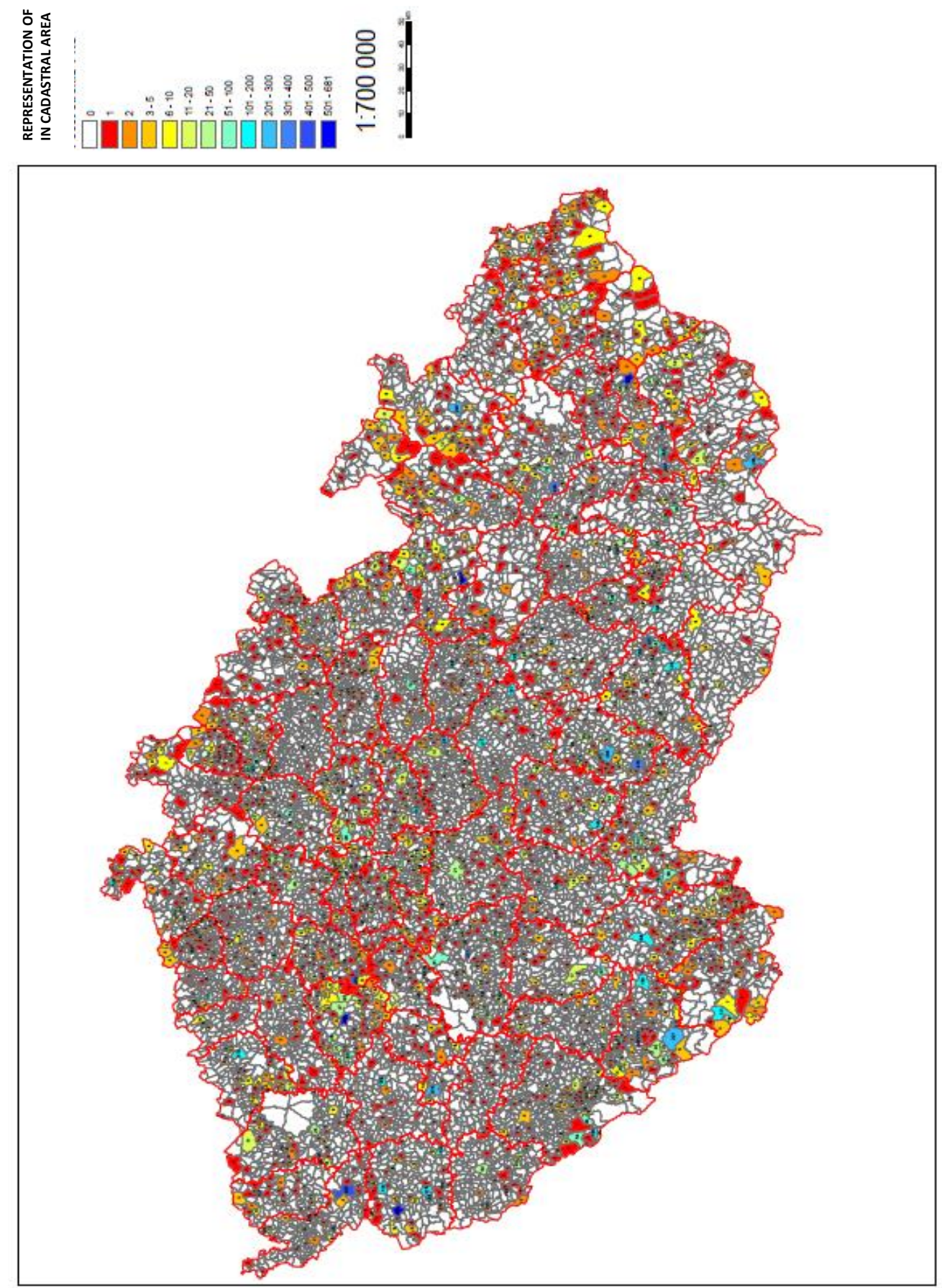
Map. 2: Representation of species of memorial trees in the Czech Republic in cadastral area
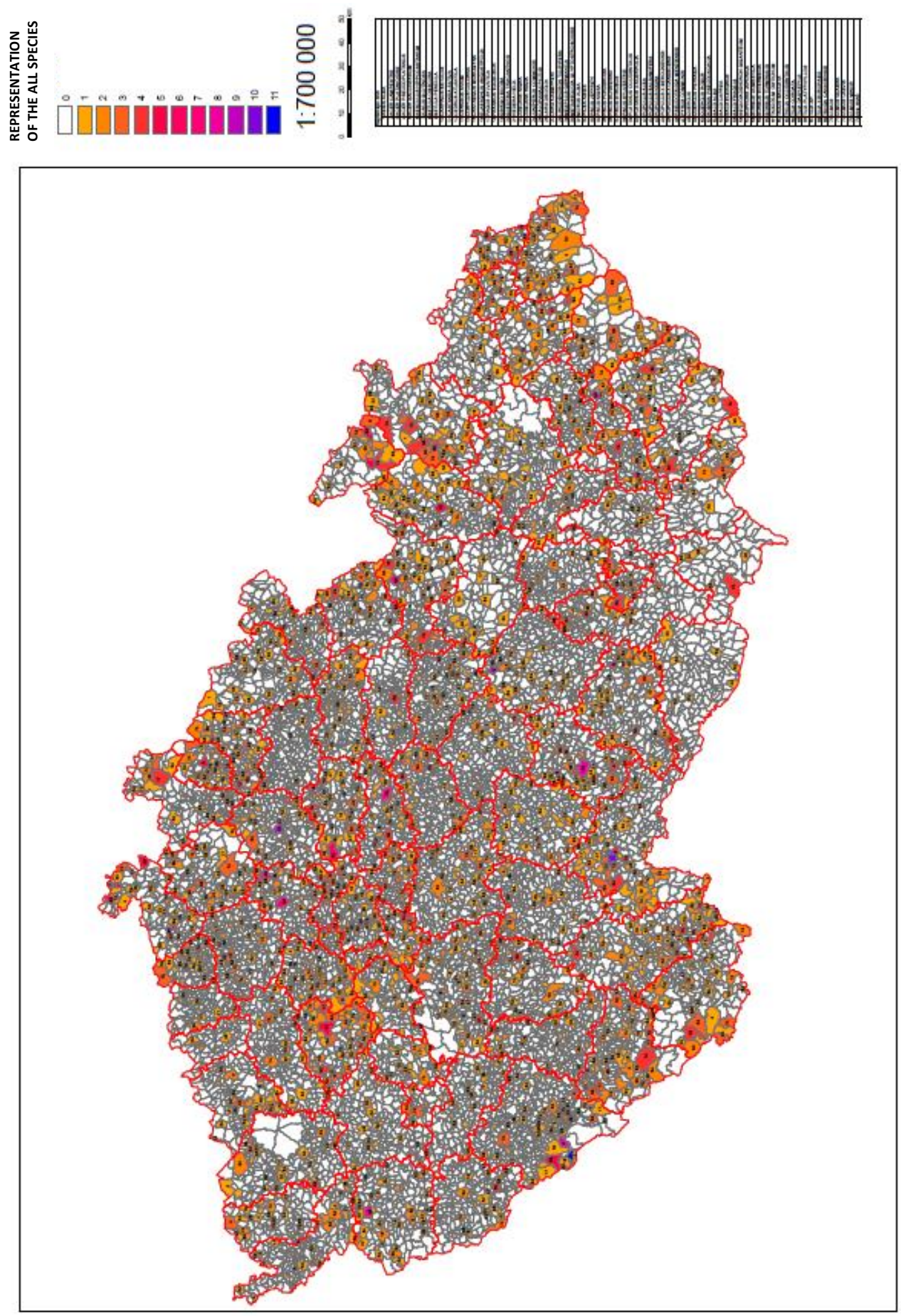
Map. 3: The largest girth of a memorial tree in the Czech Republic in cadastral area
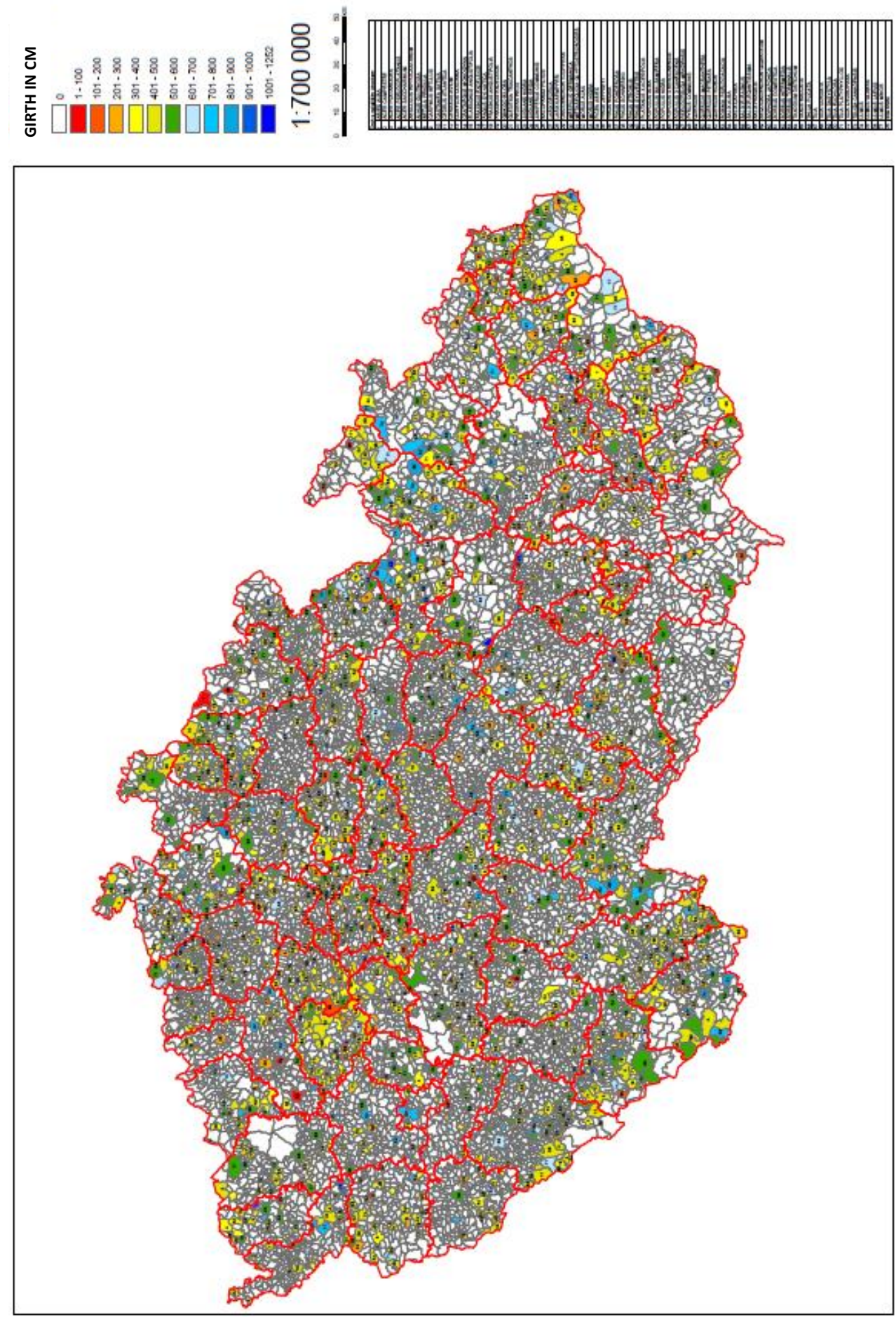
Map. 4: Representation of memorial trees in bioregions in the Czech Republic
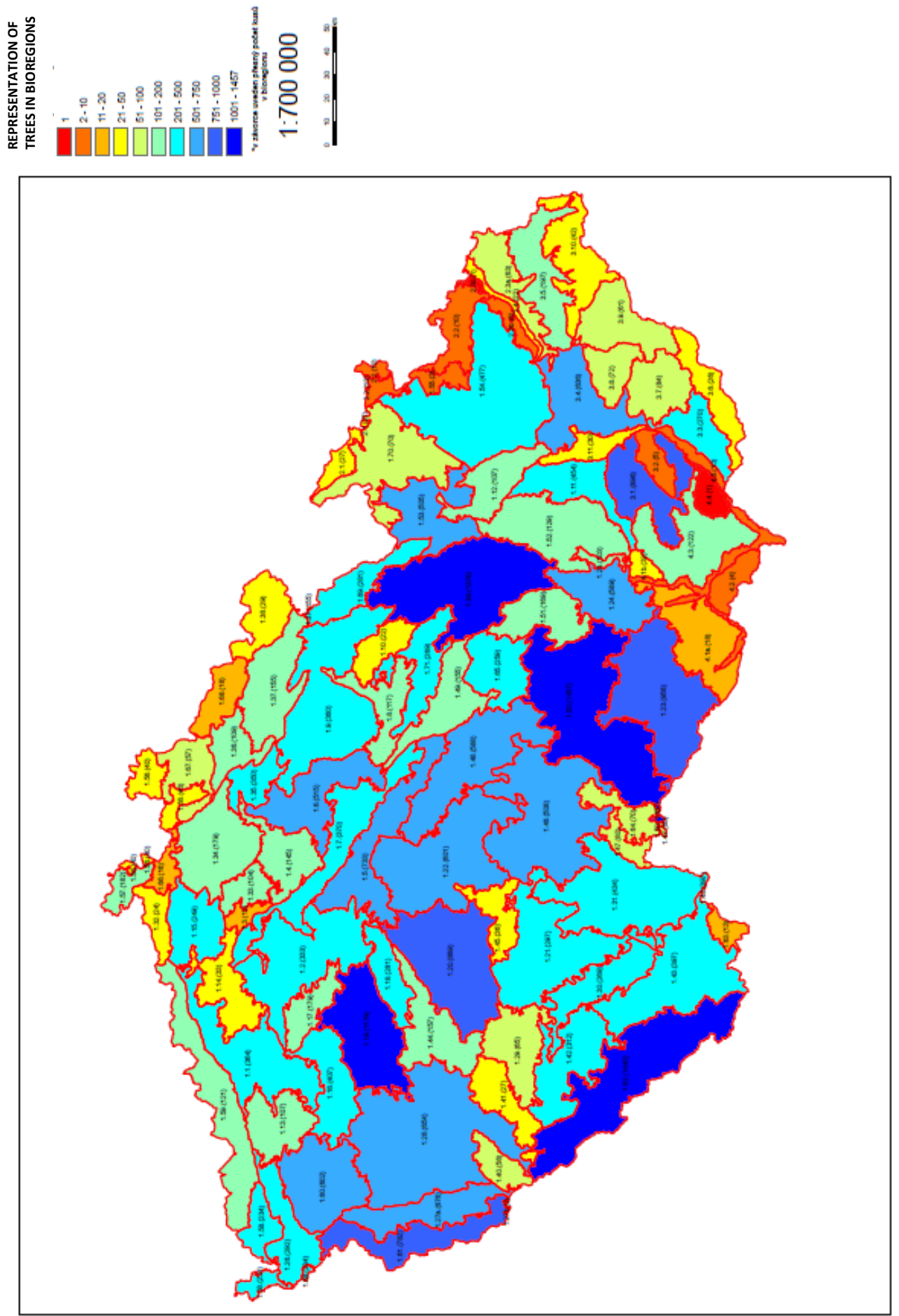
Journal of Landscape Ecology (2017), Vol: 10 / No. 2

Map. 5: Representation of memorial trees in bioregions in the Czech Republic

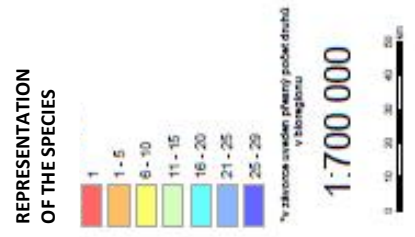

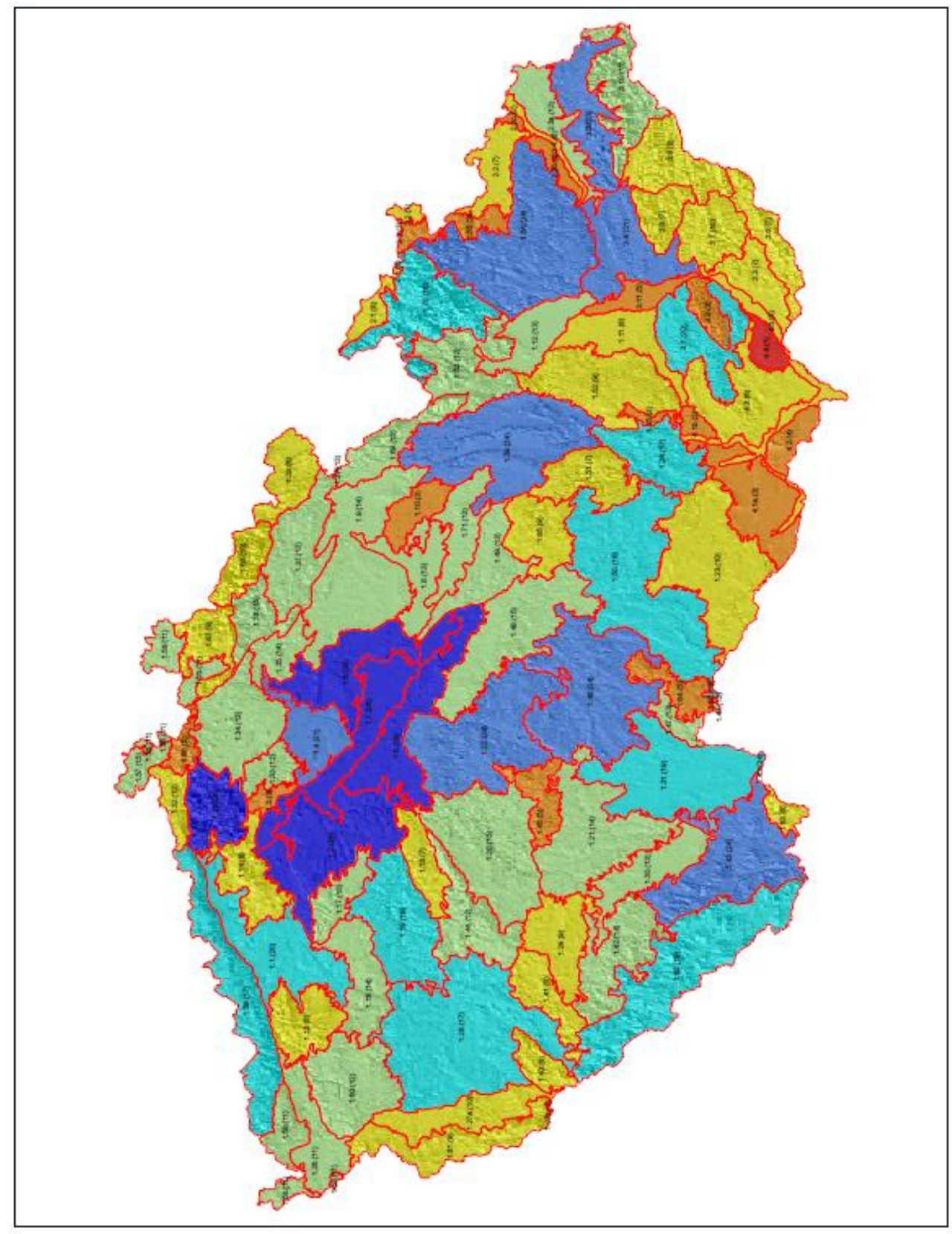

